\begin{tabular}{|l|l|l|l|}
\hline $\begin{array}{l}\text { Eiszeitalter und Gegenwart } \\
\text { Quaternary Science Journal }\end{array}$ & 57/1-2 & $2-24$ & Hannover 2008 \\
\hline
\end{tabular}

\title{
Radiocarbon dating and its applications in Quaternary studies
}

\author{
IRKA HAJDAS ${ }^{*}$
}

\begin{abstract}
This paper gives an overview of the origin of ${ }^{14} \mathrm{C}$, the global carbon cycle, anthropogenic impacts on the atmospheric ${ }^{14} \mathrm{C}$ content and the background of the radiocarbon dating method. For radiocarbon dating, important aspects are sample preparation and measurement of the ${ }^{14} \mathrm{C}$ content. Recent advances in sample preparation allow better understanding of long-standing problems (e.g., contamination of bones), which helps to improve chronologies. In this review, various preparation techniques applied to typical sample types are described. Calibration of radiocarbon ages is the final step in establishing chronologies. The present tree ring chronology-based calibration curve is being constantly pushed back in time beyond the Holocene and the L ate Glacial. A reliable calibration curve covering the last $50,000-55,000 \mathrm{yr}$ is of great importance for both archaeology as well as geosciences. In recent years, numerous studies have focused on the extension of the radiocarbon calibration curve (INTCA L working group) and on the reconstruction of palaeo-reservoir ages for marine records.
\end{abstract}

\section{[Die Radiokohlenstoffmethode und ihre Anwendung in der Quartärforschung]}

Kurzfassung: Dieser Beitrag gibt einen Überblick über die Herkunft von Radiokohlenstoff, den globalen K ohlenstoffkreislauf, anthropogene Einflüsse auf das atmosphärische ${ }^{14} \mathrm{C}$ und die Grundlagen der Radiokohlenstoffmethode. Probenaufbereitung und das $M$ essen der ${ }^{14} \mathrm{C}$ K onzentration sind wichtige A spekte im Zusammenhang mit der Radiokohlenstoffdatierung. Gegenwärtige Fortschritte in der Probenaufbereitung erlauben ein besseres Verstehen lang bekannter Probleme (z.B. die K ontamination von K nochen) und haben zu verbesserten Chronologien geführt. In diesem Ü berblick werden verschiedene A ufbereitungstechniken für typische Probengattungen beschrieben. Der letzte Schritt beim Erstellen einer Chronologie ist die Kalibration der Radiokohlenstoffalter. Die gegenwärtige auf B aumringzeitreihen basierende K alibrationskurve wird stetig über das Holozän und Spätglazial hinaus erweitert. Eine zuverlässige K alibrationkurve für die letzten 50.000-55.000 Jahre ist von herausragender Bedeutung sowohl für die Archäologie als auch die Geowissenschaften. In den letzten Jahren haben zahlreiche Studien an der Erweiterung der Radiokohlenstoff-K alibrationskurve (INTCAL working group) und an der Rekonstruktion des Paläo-Reservoireffekts in marinen A rchiven gearbeitet.

K eywords: Radiocarbon dating, sample preparation, calibration, Q uaternary

\footnotetext{
*A ddress of author: I. Hajdas, I In B eam Physics, ETH/PSI Zürich, Schafmattstrasse 20, 8093 Zürich, Switzerland. E-M ail: hajdas@ phys.ethz.ch
} 


\section{Introduction}

The cosmogenic (produced by cosmic rays) isotope of carbon ${ }^{14} \mathrm{C}$, also called radiocarbon, is the heaviest of the three isotopes of this element occurring in nature. The two stable isotopes ${ }^{12} \mathrm{C}$ and ${ }^{13} \mathrm{C}$ (representing $99.9 \%$ and $0.1 \%$, respectively, of all natural carbon) originate from the primordial composition of the planet. Although ${ }^{14} \mathrm{C}$ takes up only a minute fraction of the carbon content (10-12), its presence in carbon-bearing materials and the halflife $\left(T_{1 / 2}\right)$ of $5730 \pm 40 \mathrm{yr}$ (Godwin 1962) form the basis for important geochronological and environmental applications.

Cosmic rays hitting the Earth's atmosphere produce cascades of secondary particles. Thermal neutrons, which are products of cosmic ray interaction, react with nitrogen of the atmosphere (Fig. 1). On average, 2 atoms $\mathrm{cm}^{-2}$ of ${ }^{14} \mathrm{C}$ are produced in the atmosphere every second. Oxidised to $\mathrm{CO}$ and $\mathrm{CO}_{2}$ molecules, which takes weeks and weeks to months, respectively (Rom et al. 2000), ${ }^{14} \mathrm{C}$ is then quickly mixed within the atmosphere. M onitoring of the atmospheric ${ }^{14} \mathrm{C}$ levels of the nuclear tests in the 1960 s has shown that inter-hemispheric mixing occurs in one to two years. For the purpose of radiocarbon dating, the difference between various regions is marginal. However, the difference between the hemispheres (ca. $5 \%$ ) might be reconsidered through regional calibration (M cCormac et al. 2004).

A ge measurements are possible because ${ }^{14} \mathrm{C}$ becomes a part of all organic and inorganic carbon compounds and a steady state between the uptake (photosynthesis or food) and the decay of ${ }^{14} \mathrm{C}$ exists as long as the organism is alive (LIBBy et al. 1949). After death, the only remaining process is decay (beta decay in which ${ }^{14} \mathrm{C}$ decays to nitrogen). M easurement of the beta-decay rate (conventional method) or counting the remaining ${ }^{14} \mathrm{C}$ atoms (A M S method) gives a measure of the time that elapsed since the steady state was broken. The half-life of $5730 \pm 40 \mathrm{yr}$ (GODWIN 1962) allows the application of this method for the last 50,000-55,000 yr.
The main processes of the carbon cycle also control the ${ }^{14} \mathrm{C}$ exchange of the atmosphere with other main reservoirs: the ocean, the biosphere and the sediments (Fig. 2). The very fast exchange rate between the atmosphere and the biosphere assures equal ${ }^{14} \mathrm{C}$ concentration in contemporary living organisms, which is important for the use of radiocarbon as a dating tool. The ocean, which is the largest carbon reservoir, has a long residence time of ${ }^{14} \mathrm{C}$ and in consequence, the surface water and the deep-water

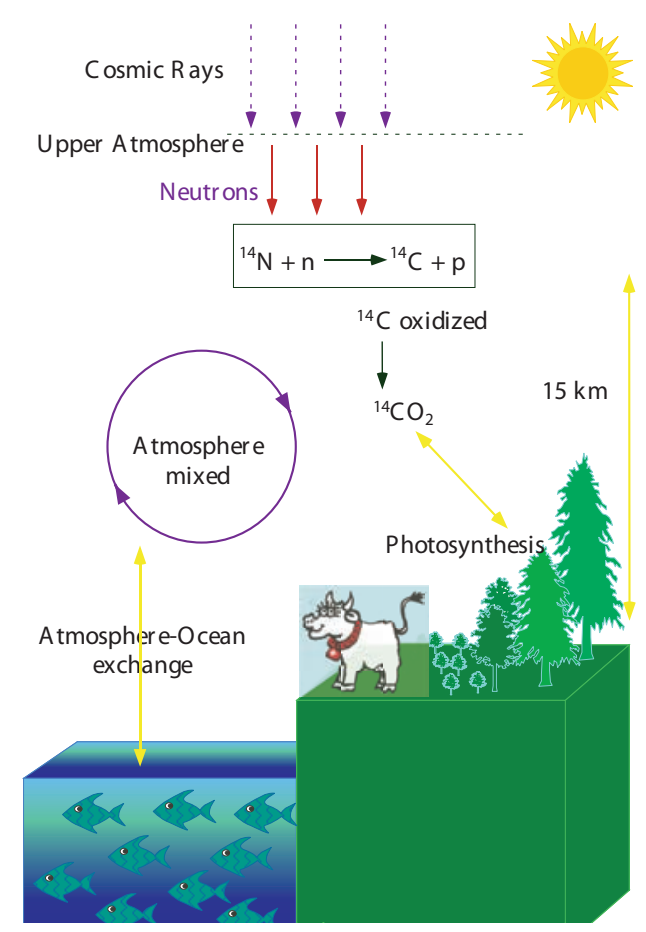

Fig. 1: Production and distribution of cosmogenic ${ }^{14} \mathrm{C}$. Produced mainly in the upper atmosphere due to interaction of thermal neutrons with nitrogen, ${ }^{14} \mathrm{C}$ is relatively quickly oxidised and mixed in the atmosphere. Through photosynthesis, it enters the biosphere and through gas exchange, the oceans.

A bb. 1: Produktion und Verbreitung von kosmogenem ${ }^{14} \mathrm{C}$. Das hauptsächlich in der oberen $\mathrm{A}$ tmosphäre durch Interaktion von thermischen N eutronen mit Stickstoff produzierte ${ }^{14} \mathrm{C}$ wird relativ schnell oxidiert und in der A tmosphäre vermischt. Durch Photosynthese gelangt es in die B iosphäre und durch Gasaustausch in die Ozeane. 
masses have ages relative to the atmosphere, giving rise to the so-called reservoir age.

Due to various mechanisms such as changes in production rate and/or in the exchange rate between the carbon reservoirs, the atmospheric ${ }^{14} \mathrm{C}$ content fluctuates over time. These variations affect radiocarbon dating and often limit precision of age estimates.

\section{Production rate and global carbon cycle.}

In general, the cosmic rays flux remains constant (Vogt et al. 1990) and observed fluctuations in production rate of atmospheric ${ }^{14} \mathrm{C}$ are controlled by geomagnetic field strength as well as solar activity. In effect, a correlation exists between the number of solar spots (active sun) and the production rate of cosmogenic isotopes. The influence of solar and geomagnetic shielding on the production rate of cosmogenic isotopes can be simulated (MASARIK \& BEER 1999). B ased on these simulations, the globally averaged production rate calculated for ${ }^{14} \mathrm{C}$ is 2.02 atoms $\mathrm{cm}^{-2} \mathrm{~s}^{-1}$.

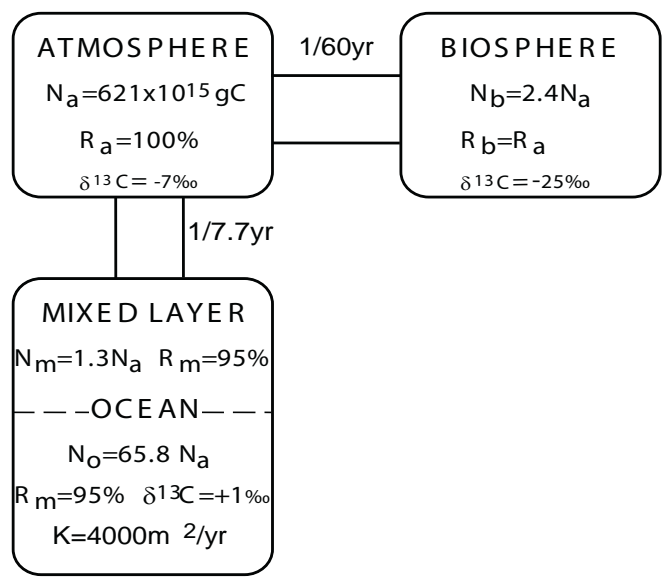

Fig. 2: The global carbon cycle (parameters used by Siegenthaler et al. 1980). $\mathrm{N}_{\mathrm{i}}=$ amount of carbon in reservoir $\mathrm{i} ; \mathrm{R}_{\mathrm{i}}={ }^{14} \mathrm{C} /{ }^{12} \mathrm{C}$ ratio; $\delta^{13} \mathrm{C}=$ isotopic fractionation

A bb. 2: Der globale Kohlenstoffkreislauf (mit den Kenngrößen verwendet von Siegenthaler et al. 1980). $N_{i}=$ M enge $K$ ohlenstoff im Reservoir $i ; R_{i}=$ ${ }^{14} \mathrm{C} /{ }^{12} \mathrm{C}$ Verhältnis; $\delta^{13} \mathrm{C}=$ isotopische Fraktionierung.
Various natural archives of cosmogenic isotopes have documented variability of production rate with time. For example, higher production rates of the cosmogenic isotopes ${ }^{10} \mathrm{Be}$ and ${ }^{14} \mathrm{C}$ are observed in ice cores and tree rings from the most pronounced periods of low solar activity: the Maunder, Wolf and Spörer minima, when the shielding was weaker (BEER et al. 1988). Variations in the strength of the geomagnetic dipole are also reconstructed using records of relative palaeointensity of the deep-sea sediments (Channell et al. 2000; Laj et al. 2000). A comparison of production rates derived from geomagnetic strength with the ice core record of ${ }^{10} \mathrm{Be}$ shows a striking correlation ( $\mathrm{L}_{\mathrm{A}}$ ) et al. 2002). Relatively short changes (events) have been observed during the last $50 \mathrm{ka}$. Higher production rates of the cosmogenic isotopes ${ }^{10} \mathrm{Be}$, ${ }^{36} \mathrm{Cl}$ and ${ }^{14} \mathrm{C}$ characterised periods/intervals of the Laschamp (41 ka) and M ono Lake (32 ka) geomagnetic excursions when the intensity of the geomagnetic field was low (Fig. 3) (HUGHEN et al. 2004a; L AJ et al. 2002; VoelKer et al. 2000; WAGNER et al. 2000).

Distribution of ${ }^{14} \mathrm{C}$ within and between reservoirs of carbon affects atmospheric ${ }^{14} \mathrm{C}$ content. The main mechanism of these changes is climatic variability because the ocean, which is the largest $C$ reservoir (Fig. 2), is also an important component of the Earth's climate system. For example, changes of deep ocean ventilation during the glaciations had an impact on the atmosphere-ocean exchange of ${ }^{14} \mathrm{C}$. $M$ odels have been devel oped to reconstruct the effect of such changes in the ocean ventilation on the ${ }^{14} \mathrm{C}$ inventory of both reservoirs. The simple box model of the ocean-atmosphere showed that reduced ventilation rates result in an increase, whereas the vigorous ocean ventilation results in a decrease of atmospheric ${ }^{14} \mathrm{C}$ content (Siegenthaler et al. 1980).

\section{Anthropogenic impact on atmospheric ${ }^{14} \mathrm{C}$}

\subsection{Suess effect}

The industrial revolution of the late $19^{\text {th }}$ century changed the ${ }^{14} \mathrm{C}$ content of the atmosphere. The 


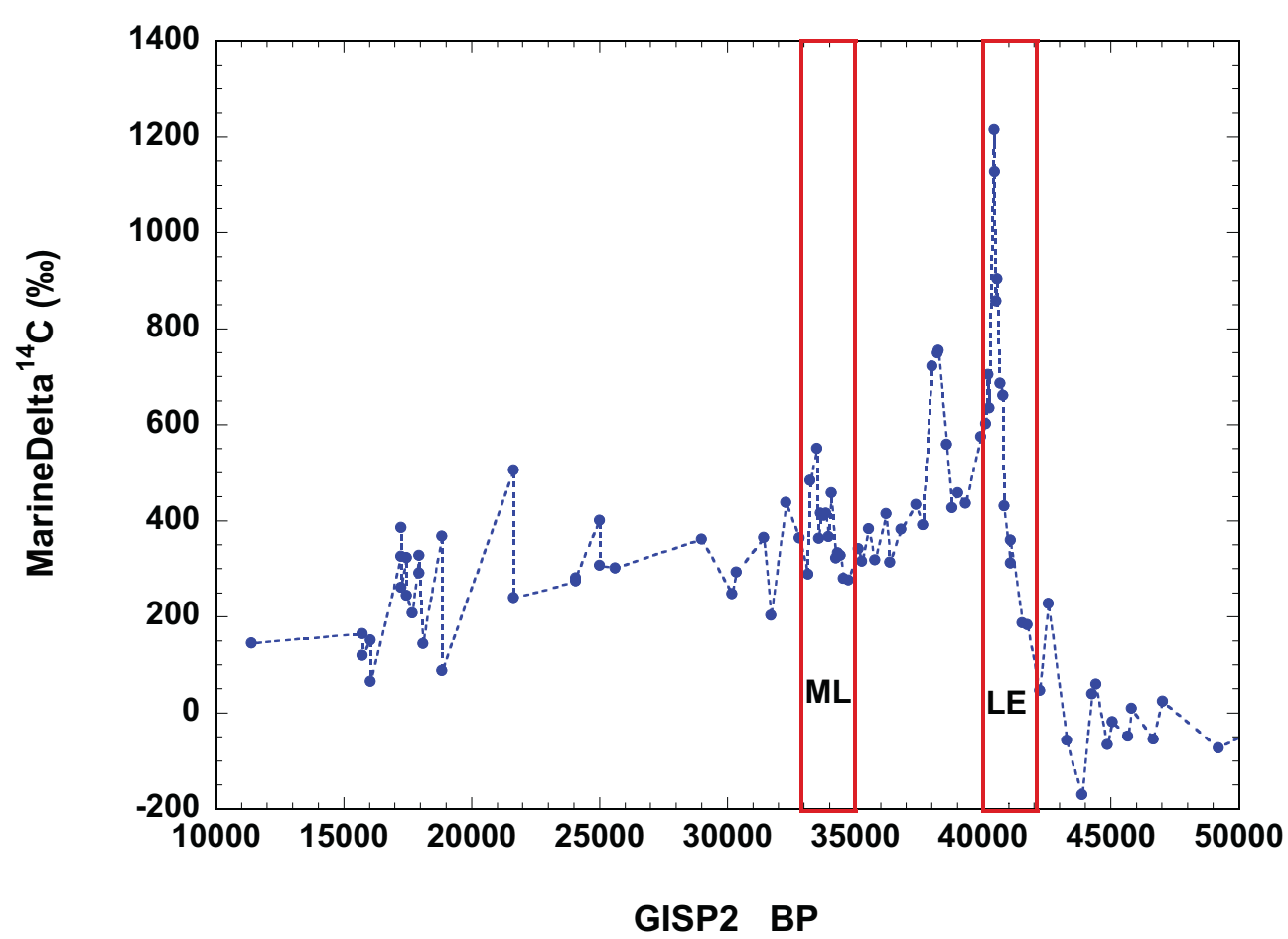

Fig. 3: Variations in ${ }^{14} \mathrm{C}$ concentration in foraminifera shells from L ate Pleistocene Icelandic Sea sediments (VOELK ER et al. 2000). The increases in marine $\triangle{ }^{14} \mathrm{C}$, the measure of difference from the 'present day, i.e. 1950 AD ${ }^{14} \mathrm{C}$ level (Stuiver \& Polach 1977), observed at 40-42 ka and 33-35 ka BP, coincide with low relative magnetic field intensity ( $L_{A}$ J et al. 2002), i.e. weak geomagnetic shielding of the $L$ aschamp $E$ vent (LE) and Mono Lake (ML) event, respectively.

A bb. 3: Variationen in der ${ }^{14} \mathrm{C}$ K onzentration in Foraminiferenschal en aus spätplei stozänen Sedimenten aus dem Isländischen M eer (VoelKer et al. 2000). Der A nstieg des marinen $\Delta^{14} \mathrm{C}$, als M aß des U nterschiedes zu heutigen, d.h. 1950 A D ${ }^{14} \mathrm{C}$ Niveau (Stuiver \& Polach 1977), der bei 40-42 ka und 33-35 ka auftritt, fällt mit einer niedrigen Intensität des magnetischen Feld zusammen ( $L_{\text {Aj }}$ et al. 2002), d.h. mit einer schwachen geomagnetischen A bschirmung während des L aschamp Exkursions ( $L E)$ und des M ono L ake (ML) Exkursions.

increased burning of fossil fuels, which are free of ${ }^{14} \mathrm{C}$ (virtually all of the ${ }^{14} \mathrm{C}$ fixed in organic matter from millions of years ago has already decayed), added a significant part of ${ }^{14} \mathrm{C}$ free carbon dioxide to the atmosphere. In effect, the atmospheric ${ }^{14} \mathrm{C} /{ }^{12} \mathrm{C}$ ratio was lowered and thus, radiocarbon ages measured in postindustrial times will overestimate the real age of the sample. The effect was named after $\mathrm{H}$ ans Suess who first described it in the 1950s (SUESS 1955). The observed effect of fossil fuel burning is most pronounced in the air from urban areas (Levin et al. 2008; Pawelczyk \& Pazdur 2004).

\subsection{The ${ }^{14} \mathrm{C}$ 'bomb peak'}

The nuclear tests in the 1950s caused an increased stream of thermal neutrons into the stratosphere, which produced additional ${ }^{14} \mathrm{C}$ atoms and created an excess ${ }^{14} \mathrm{C}$ activity in the atmosphere (Fig. 4). Bomb produced ${ }^{14} \mathrm{C}$ was identified soon after the tests started and continuous monitoring has been carried out ( $\mathrm{N} Y$ DAL et al. 1984; Nydal \& L OVSETH 1965, 1983). The peak (ca. 100\% above the normal levels) reached its maximum in 1963 in the northern hemisphere, where most of the tests took place. In the southern hemisphere, the bomb peak 


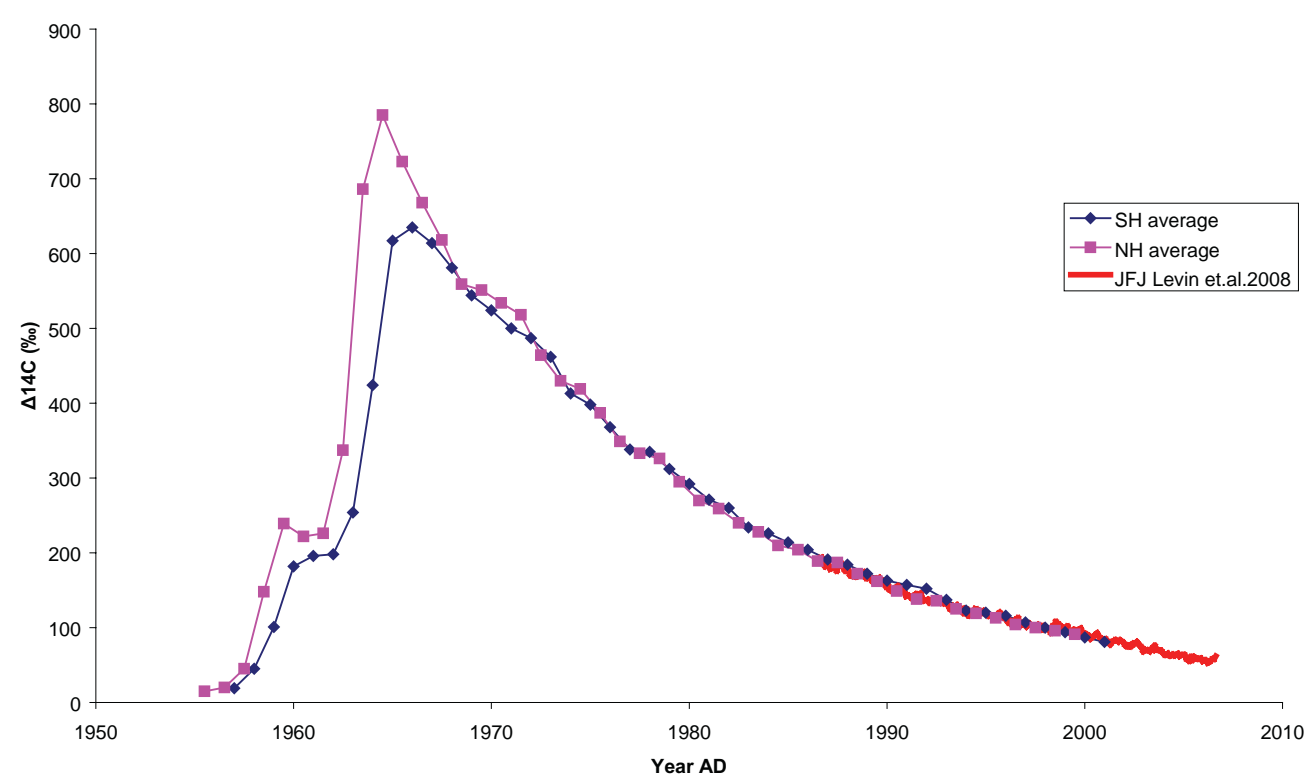

Fig. 4: The ${ }^{14} \mathrm{C}$ 'bomb peak'. M easurements of post $1950 \mathrm{AD}$ atmospheric ${ }^{14} \mathrm{C}$ concentration for both the Northern (NH) and Sothern Hemispheres (SH) compiled by HuA \& BARBetTI (2004). The monthly atmospheric ${ }^{14} \mathrm{C}$ data sets from measurements at the High A I pine Research Station J ungfraujoch (J FJ) show the present level of atmospheric $\Delta^{14} \mathrm{C}$ (LEVIN et al. 2008).

A bb. 4: Der ${ }^{14} \mathrm{C}$ „B omben-Peak“. Die nach $1950 \mathrm{AD}$ durchgeführten M essungen der ${ }^{14} \mathrm{C}$ K onzentration für sowohl die Nördliche (NH) als die Südliche Hemisphäre (SH) wurden von HuA \& BARBETTI (2004) kompiliert. Der monatliche ${ }^{14} \mathrm{C}$-Datensatz von $\mathrm{M}$ essungen an der Hochalpinen Forschungsstation J ungfraujoch (J FJ) zeigt das gegenwärtige Nivea des atmosphärischen $\Delta^{14} \mathrm{C}$ (L EVIN et al. 2008).

reached lower values (ca. $80 \%$ of normal level) and was delayed by ca. two years. After the ban on above-ground nuclear tests in 1963, the atmospheric ${ }^{14} \mathrm{C}$ content began to decrease mainly due to uptake by the ocean and the biosphere (NYDAL et al. 1980). During the last decade, the decline has been caused mostly by dilution of the atmospheric $\mathrm{CO}_{2}$ with ${ }^{14} \mathrm{C}$-free fossil fuel $\mathrm{CO}_{2}$ (ca. 2-3 per mil $\mathrm{yr}^{-1}$ ) (LEVIN et al. 2008). Continuous monitoring of the atmospheric ${ }^{14} \mathrm{C} /{ }^{12} \mathrm{C}$ ratio during the years following the nuclear tests provided the basis for environmental studies (LeVIn \& Kromer 2004; RozAnski et al. 1995). A pplications range from studies of the ocean circulation, $\mathrm{CO}_{2}$ uptake, and carbon storage in soils to medical and forensic studies as well as detection of forgeries (Levin \& Hesshaimer 2000; Spalding et al. 2005a,b; TAY LOR et al. 1992).

\section{Radiocarbon dating}

The method as established by Libby and coworkers in late 1940s assumed a constant atmospheric ${ }^{14} \mathrm{C}$ content. For the reasons discussed above, such an assumption is invalid, as shown by more precise measurements of tree rings performed in early 1950s. M oreover, the half-life $T_{1 / 2}=5568$ yrs used by ARNOLD $\&$ LIBBY (1949) was later found to be off by $3 \%$ from its real value. However, an agreement has been reached that conventional radiocarbon ages (Libby ages) are calculated using the Libby half-life and then later calibrated (where a calibration curve is available) to obtain calendar ages that correspond to the measured ${ }^{14} \mathrm{C}$ concentration (age). 


\subsection{Conventional radiocarbon ages (Libby radiocarbon ages)}

The ${ }^{14} \mathrm{C}$ concentration measured either by counting (KROMER \& MünNICH 1992; HogG et al. 2006 and references therein) or A M S techniques (FINKEL \& SUTER 1993; Jull \& BURR 2006 and references therein) provides information about the time elapsed since the time of deposition or death.

The activity of ${ }^{14} \mathrm{C}$ can be measured by counting of beta particles emitted by decaying ${ }^{14} \mathrm{C}$ or by measuring the ${ }^{14} \mathrm{C} /{ }^{12} \mathrm{C}$ ratio using accelerator mass spectrometry (AMS). Both methods allow the dating of natural carbon-bearing material. A fter death or deposition, the equilibrium between uptake from the environment (atmosphere, ocean, lake) and ${ }^{14} \mathrm{C}$ decay is broken. When the, new ${ }^{14} \mathrm{C}$ atoms cannot be incorporated by the organism, the activity begins to decrease with a half-life of $5730 \mathrm{yr}$. A pplication of the decay law for radiocarbon dating requires that the activity of the organic matter after the death of the organism changes only due to radioactive decay (i.e. the dated matter was a closed system). Radiocarbon age (conventional or Libby radiocarbon age) $\mathrm{T}$ can be cal culated thusly:

$\mathrm{T}=8033 \ln \left(\mathrm{A}_{\mathrm{A}} \mathrm{A}_{0}\right)$

$\mathrm{A}={ }^{14} \mathrm{C}$ activity at the time of dating

$\mathrm{A}_{0}=$ initial ${ }^{14} \mathrm{C}$ activity at time $\mathrm{t}_{0}$ (deposition, death)

$\mathrm{T}_{1 / 2} / \mathrm{ln} 2=8033 \mathrm{yr}$, where

$\mathrm{T}_{1 / 2}^{1 / 2}=5568 \mathrm{yr}$ half-life used by Libby

In order to cal culate ages, the initial activity $A_{0}$ at time $t_{0}$ must be known. A s already discussed, $A_{0}$ is not constant over time and therefore an activity of pre-industrial wood grown in $1890 \mathrm{AD}$ was chosen as reference. A lthough the half-life $\mathrm{T}_{1 / 2}$ of $5568 \mathrm{yr}$ (Libby half-life) is underestimated, it was accepted for use in the cal culation of conventional radiocarbon ages (OLSON et al. 1966; Stuiver \& Polach 1977). Conventional radiocarbon age can then be corrected and expressed in radiocarbon ages for the half-life of 5730 years $\left(t_{5730}=1.03 t_{\text {Libby }}\right)$.
In addition, small variations in the initial activity of the sample are related to the mass dependent fractionation of carbon isotopes by chemical and physical reactions that occur in nature, e.g. photosynthesis in the case of plants (which is then passed to animal tissue via the food chain) or precipitation processes of carbonates. The degree of fractionation in a dated sample, defined as a depletion or enrichment of the isotope relative to the standard material (CRAIG 1953), is different for various materials (Craig 1954; Stuiver \& Polach 1977). Counting techniques use mass spectrometry measurements of gas split of $\mathrm{CO}_{2}$ in order to obtain the correction value and some of AMS facilities measure the ${ }^{14} \mathrm{C} /{ }^{13} \mathrm{C}$ as well as ${ }^{13} \mathrm{C} /{ }^{12} \mathrm{C}$ ratios, which then can be applied to correct for fractionation.

Because the ${ }^{14} \mathrm{C}$ fractionation effect is approximately twice as much for ${ }^{13} \mathrm{C}$, the correction applied to the ${ }^{14} \mathrm{C}$ content measured in the dated material is two times $\delta^{13} \mathrm{C}$. Recently Mook \& Van Der Plicht (1999), Reimer et al. (2004C) and VAN der PLICHT \& HOgg (2006) summarised the conventions used for age calculation. The nomenclature used by these authors is summarised below. The ${ }^{14} \mathrm{C}$ concentration or ${ }^{14} \mathrm{C}$ activity of a sample is described as a fraction of reference material:

${ }^{14} \mathrm{a}={ }^{14} \mathrm{~A}$ (sample) $/{ }^{14} \mathrm{~A}$ (reference)

${ }^{14} \mathrm{~A}$ (reference) or standard activity corresponds to $95 \%$ of the activity of a specific batch of the Oxalic Acid standard HOxI in the year 1950 $A D$. The secondary standard $\mathrm{HO} \times 2$ used presently by most laboratories has a defined activity ratio of 1.2933 in relation to the original $\mathrm{HOx} 1$ (ManN 1983).

${ }^{14} \mathrm{~A}^{0}{ }_{\mathrm{RN}}=0.95{ }^{14} \mathrm{~A}^{0}{ }_{\text {OX1N }}=0.7459{ }^{14} \mathrm{~A}^{0}{ }_{\mathrm{OX} 2 \mathrm{~N}}=$
$13.56 \pm 0.07 \mathrm{dpm} \mathrm{gC^{-1 }}$ $\mathrm{dpm} \mathrm{gC}^{-1}=$ disintegrations

per minute and per gram of carbon

${ }^{14} A_{R N}$ is the specific activity of the standard corrected for isotopic fractionation to 
$\delta^{13} \mathrm{C}=-25 \%$ for $\mathrm{HO} 2$ and $\delta^{13} \mathrm{C}=-19.0 \%$ for $\mathrm{HOX} 1$

The activity ratio of the measured sample or concentration is defined as:

${ }^{14} \mathrm{a}={ }^{14} \mathrm{~A} /{ }^{14} \mathrm{~A}_{\mathrm{RN}}$

This value is independent of when the measurement was carried out because it is relative to the standard of $1950 \mathrm{AD}$. The relative activity is expressed in per mil and defined as

${ }^{14} \delta={ }^{14} \mathrm{a}-1$

The measured isotopic ratio has to be corrected for mass fractionation, which occurs during chemical and physical processes in nature (see above). The ${ }^{14} \mathrm{C}$ activity and the relative content are normalised to ${ }^{13} \delta=-25 \%$ (wood):

$$
{ }^{14} \mathrm{a}_{\mathrm{N}}={ }^{14} \mathrm{a}\left[\frac{1+{ }^{13} \delta_{\mathrm{N}}}{1+{ }^{13} \delta}\right]^{2}={ }^{14} \mathrm{a}\left[\frac{0.975}{1+{ }^{13} \delta}\right]^{2}
$$

A nother symbol for the activity ratio has been proposed by ReImer et al. (2004c) and is frequently used in publications:

$\mathrm{F}^{14} \mathrm{C}={ }^{14} \mathrm{a}_{\mathrm{N}}$

This expression stands for the activity ratio of the measured sample to the standard corrected for the fractionation (as defined above) and for the background activity (blank values for A M S samples). Similar to the convention discussed above and published by Stuiver \& POLACH (1977), the radiocarbon age $T$ is calculated using the measured and normalised values of ${ }^{14} \mathrm{a}_{\mathrm{N}}$ or $\mathrm{F}^{14} \mathrm{C}$ :

$\mathrm{T}=-8033 \ln \left(\mathrm{F}^{14} \mathrm{C}\right)$ or $\mathrm{T}=-8033 \ln \left({ }^{14} \mathrm{a}_{\mathrm{N}}\right)$

Conventional radiocarbon ages are reported as B efore Present (BP), where $0 \mathrm{BP}=$ year 1950 $A D$.

Van Der Plicht \& Hogg (2006) define the frequently used value of $\Delta^{14} C$ (Stuiver \& Po$\angle A C H$ 1977), which illustrates the variations of ${ }^{14} \mathrm{C}$ in the atmosphere. The original ${ }^{14} \mathrm{C}$ content of the measured sample can be reconstructed for samples of known calendar age (tree rings, varves, U/Th dated carbonates). The measured ${ }^{14} \mathrm{C}$ content of the sample in year $1950 \mathrm{AD}$ is corrected for the decay of ${ }^{14} \mathrm{C}$ (with the correct decay constant) during the time that has elapsed since the sample was formed, $t_{i}$ :

$$
\begin{aligned}
& { }^{14} \delta_{N}^{i}={ }^{14} a_{N}^{i}-1 \\
& { }^{14} a_{N}^{i}={ }^{14} a_{N} \exp \left\{-\left(t_{i}-1950\right) / 8267\right\} \\
& =F^{14} \mathrm{C} \exp \{\mathrm{calBP} / 8267\}
\end{aligned}
$$

where $\mathrm{T}_{1 / 2} / \mathrm{ln} 2=8267 \mathrm{yr}$ for $\mathrm{T}_{1 / 2}=5730 \mathrm{yrs}$ and calBP is the calendar age (cal BP) of the sample.

\subsection{Precision and accuracy of measured ra- diocarbon ages}

Precision characterises the degree of agreement among a series of individual measurements, i.e. the uncertainty of the measurement and is often quoted as the one-sigma error. This includes statistical error of counting atoms (AMS) or beta particles as well as uncertainty of measuring standards and blank values included in the calculation of radiocarbon ages. The counting error can be reduced by improved counting statistics. This can be achieved by increasing counting time. In the AMS technique, this is usually limited by the sample size as well as performance and stability of the A M S device.

Accuracy describes the difference between the calculated radiocarbon and the true age of a sample. This is independent of the measurement precision, i.e. radiocarbon ages can be very precise but their accuracy might be low or vice versa (Scott et al. 2007a). Radiocarbon laboratories check their accuracy using measurements of known age samples (for example a set of $C$ samples available from IAEA). $M$ oreover, regular proficiency checks known as inter-lab comparison are performed (ScOTT 2003a,b,c; Scott et al. 2004). Recently these comparison measurements were extended to various types of samples (N AY SM ITH et al. 2007; Scott et al. 2007b). 


\subsection{Calibration of radiocarbon ages}

Due to the variability of the atmospheric ${ }^{14} \mathrm{C}$ content and the used convention discussed above, radiocarbon ages are only 'defined' values and require calibration in order to obtain calendar ages. Calibration of radiocarbon ages compensates for both the error introduced by conventional (Libby) half-life $T_{1 / 2}$ and for the temporal variability of the atmospheric ${ }^{14} \mathrm{C}$ content.

Calibration is a mathematical procedure that places the measured radiocarbon ages (taken with their error) on the experimentally drawn curve. In the probabilistic calibration procedure, calendar ages, corresponding to the radiocarbon age obtained for the measured material, are given with the probability distribution $(68 \%$ and $95 \%$ confidence intervals for 1 sigma and 2 sigma error, respectively) (StuIVer $\&$ ReIMER 1986, 1989). The calibrated radiocarbon ages are then reported as 'cal $A D / B C$ ' or 'cal BP' (calendar years BP). B ecause of the wiggles on the calibration curve, the transfer to calendar time scale may have a complicated probability distribution (Fig. 5).

Nowadays, calibration can be done using calibration software available via the web site of the Radiocarbon journal (http: //www.radiocarbon.org). The calibration data used by most of the programs are based on the calibration data sets prepared and published by the International Calibration Group (INTCAL). The most recent set of data IN -

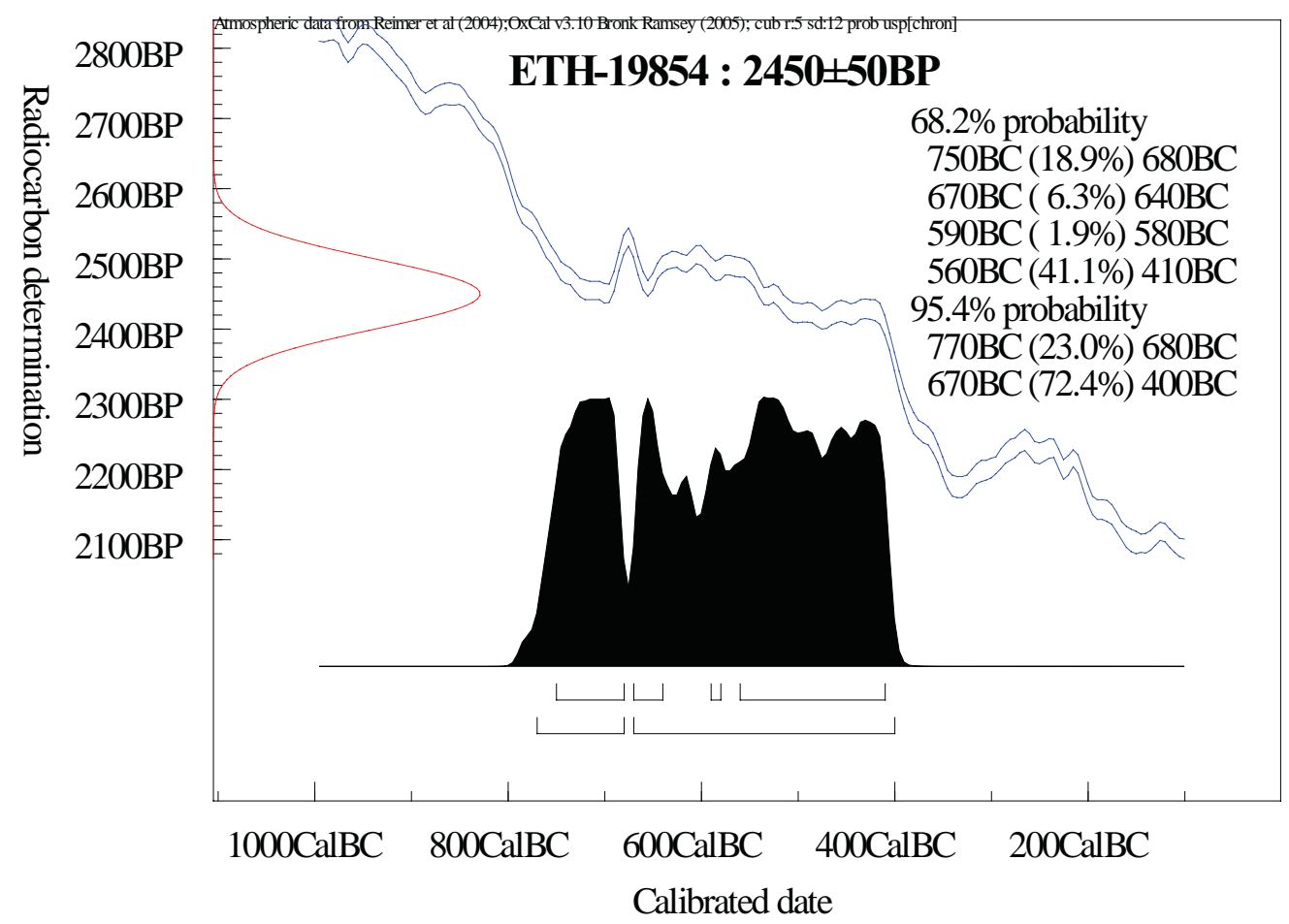

Fig. 5: Example of calibration of radiocarbon age (one of the samples from Ulandryk series, HajDAS et al. 2004b), which is in the range of an age plateau (see text). The complex nature of the calibration curve (wiggles) results in multiple calendar age intervals.

A bb. 5: B eispiel für die Kalibrierung eines Radiokohlenstoffalters (eine der Proben aus der Ulandryk Serie, $\mathrm{H}_{\text {AJd DAS }}$ et al. 2004b), welches sich im B ereich eines A Itersplateaus befindet (s. Text). Die komplexe Natur der Kalibrierungskurve („,wiggles“) resultiert in einer A nzahl von möglichen $\mathrm{K}$ alenderjahr-Intervallen. 
TCA L 04 was published in 2004 (Hughen et al. 2004b; Reimer et al. 2004a). The current state of the calibration curve and efforts to extend it to the limits of the method will be discussed later.

\section{Sample types and preparation techniques}

During the six decades of radiocarbon dating, the method has evolved towards more sophisticated applications that, in many cases, require very small sample sizes. The ultimate goal is to obtain a material for radiocarbon dating that is free of foreign carbon i.e., contaminants. Because carbon is such a common element in the environment, removing either modern (high amount of ${ }^{14} \mathrm{C}$ ) or ancient (free of ${ }^{14} \mathrm{C}$ ) contaminations has always been a challenging task. An overview of sample preparation presented here is relevant to both conventional and A M S sample preparation laboratories. The focus is how ever set on samples prepared for the AMS technique because many applications nowadays involve only minute sample amounts. While previous sample treatments were designed to remove contamination assuming that the material has been part of a closed system, present preparation involves evaluation of possible sources of contamination as well as extraction of the fractions that will give the most accurate age estimates. This requires understanding of the environment in which the dated material had been formed and preserved until sampling.

\subsection{Sample types}

The common types of samples include charcoal, wood, bones, animal tissue, textiles, paper, macroscopic remains of the plants (leaves, fruits, flowers), carbonates (corals, sediments, stalagmites and stalactites), water, air and organic matter from various sediments, soil, palaeosol and peat deposits. Depending on the sample type, an appropriate treatment is chosen to select the most relevant fraction of carbon, which will yield the accurate age of the studied object.

\subsection{Sources of contamination}

Modern dust that includes particles of, for example, hair, tissue, paper or pollen grains, is the most common source of contamination with modern carbon. In addition, bacterial growth might contaminate sediments and other organic matter during storage. Therefore, freezing or drying of the material to be dated is recommended.

Carbonates and humic acids infiltrate natural environments over the years during which the sample material has been buried in geological or archaeological settings. Diagenesis is the source of contamination that is introduced into the molecular structure of the material to be dated and such effects may often remain unnoticed. The process of exchange of carbon might lead to contamination with either young or old carbon. The most common problem in dating archaeological samples is degradation of bones. While buried in soil, they may incorporate humic acids from the environment. A nother example found in geological applications is dissolution and re-crystallization of carbonates. Different types of carbonates may be affected to different degrees.

Conservative substances used to preserve artefacts or bones will introduce either modern or old carbon. Substances which had been used in the past cannot always be tracked down and therefore a range of solvents is used that should remove most commonly used conservative substances. A Soxhlet extraction of contaminants is routinely applied in many laboratories to pre-treat wood, bone and textile samples. Some geological samples also require such treatment if they were buried in bituminous sediments.

\subsection{Treatment methods}

As the sources and types of contamination vary, so do the methods of pre-treatment developed in order to provide the most accurate radiocarbon ages. The first step in applying these methods is an assessment made on the degree of contamination. Recent samples such as well-preserved wood and charcoal, as well 
as textiles and in some cases bones, are usually viewed as intact materials where contaminants remain outside molecular structure of organic matter ( $M$ methods). In such cases macroscopic methods, which have been used for many decades by radiocarbon laboratories, are applied (VAN K LINKEN \& Hedges 1998). A small but ever increasing portion of samples are pre-treated at the molecular level where specific compounds are isolated, allowing more accurate dating of specific material such as degenerated bones, organic compounds in soil or deep-sea sediments (S-methods). With the exception of dating alpha-cellulose, isolation of specific compounds from a sample for dating would require an AM S facility to handle samples as small as $\mathrm{mg}$ and $\mu \mathrm{g}$ of carbon. The development of gas ion sources will allow an omission of the graphitisation process, which is limited by sample size, and thus direct measurement on $\mathrm{CO}_{2}$ samples as small as a couple of micrograms.

\subsubsection{Mechanical cleaning}

Sample material will undergo visual examination after its arrival in the laboratory. A II visible contaminants are removed under a binocular and the surface of the sample is cleaned if necessary. A short cleaning in an ultrasonic bath is applied to charcoal, textiles, wood and shells of molluscs and foraminifera to remove dust particles, etc. Some laboratories apply vacuuming of textiles surface because an ultrasonic bath might destroy and create a mash of the material. In the case of solid surfaces such as bones or corals, sand blasting is used to clean the surface (PATERne et al. 2004). Soft materials such as sediments have their surfaces scraped. In the case of small plant fragments washed out of sediments, remains of aquatic plants must be removed with tweezers (HAJDAS 1993; H AJDAS et al. 1993). Rootlets that might have grown in the layer are removed from peat or soil samples by sieving.

\subsubsection{The acid-alkali-acid (AAA) method}

The AAA pre-treatment is known as the standard chemical treatment of organic matter for radiocarbon dating, which is often applied to remove contamination by carbonates and humic acids (De VRIES \& BARENDSEN 1954). The first wash in acid solution (Fig. 6) removes carbonate contamination attached to the surface. The duration of this step applied by different laboratories varies depending on the treated material. A fter washing with distilled water, a treatment with a weak base (for example 0.1 $\mathrm{M} \mathrm{NaOH}$ ) is applied to dissolve humic acids. Following rinsing to neutral $\mathrm{pH}$, the final wash is a repeated with a hot acid bath to remove carbonates that precipitated from modern atmospheric $\mathrm{CO}_{2}$, which is dissolved in an alkali solution. This step is shorter than the other two and is followed with a final rinsing to neutral $\mathrm{pH}$. The AAA (or ABA, acid-base-acid) method is relatively straightforward, hence commonly used in most laboratories. However, several studies (H ATTÉ et al. 2001, HEAD \& ZHou 2000) have shown that the alkali step of AAA might be responsible for contamination of some material with modern $C$ from atmospheric $\mathrm{CO}_{2}$ dissolved during this step and incorporated into the sample structure. Such contamination cannot be entirely removed in the last acid wash if the commonly used weak $\mathrm{HCl}$ solution is applied. M aterials that require such modification of classical AAA treatment include wood, peat and palaeosols, i.e. common objects for radiocarbon dating. The effect of contamination becomes significant when old material is prepared for radiocarbon dating. HATTÉ et al. (2001) proposed alternative treatments, which can be applied to samples that are susceptible to contamination of their inner structure. These are designed to remove modern carbon in the last step of treatment (modification of the last step of the AAA (Fig. 6)). For example, modern carbonates, which replaced functional groups in the samples of old wood during acid and base steps, can be detached from the structure by stronger agents such as sulphuric acid. In contrast to hydrochloric acid, $\mathrm{H}_{2} \mathrm{SO}_{4}$ has a stronger ionic affinity for carbonates.

\subsubsection{ABOX Acid-Base-Oxidation}

A nother modification of the $A A A$ ( $A B A$ ) 


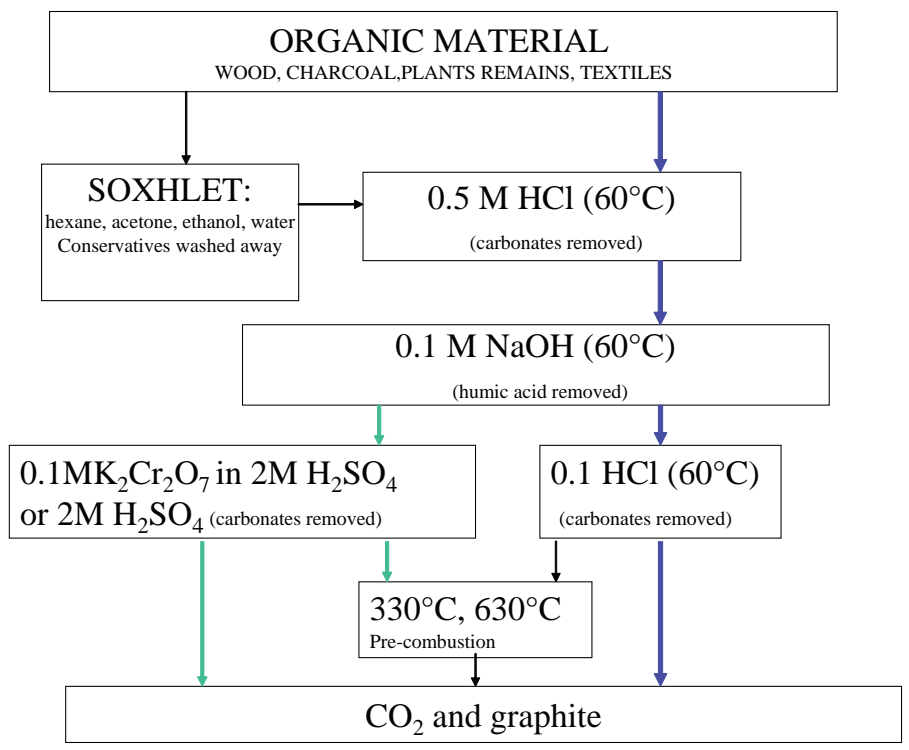

Fig. 6: Overview of pre-treatment methods routinely applied for cleaning organic material. The Soxhlet treatment is applied to material with suspected contamination caused by conservative substances or natural bituminous carbon (see text). The standard A AA treatment (blue path) might be enhanced by pre-combustion steps. A BOX (green path) is usually applied to treatment of material older than $20 \mathrm{ka}$.

A bb. 6: Überblick über Aufbereitungsmethoden, die routinemäßig für die Reinigung von organischem $M$ aterial verwendet werden. Die Soxhlet Behandlung wird angewendet an $M$ aterial, welches vermutlich durch konservierende Substanzen oder natürliches Bitumen verunreinigt ist (s. Text). Die Standard AAA B ehandlung (blauer Pfad) kann durch Vorverbrennungsschritte verstärkt werden. A BOX (grüner Pfad), wird überlicherweise für $\mathrm{M}$ aterial verwendet, welches älter als $20 \mathrm{ka}$ ist.

method involves a final oxidising step in the pre-treatment. BIRD et al. (1999) applied two methods of oxidation using a highly oxidising agent of acid dichromate solution (0.1M $\mathrm{K}_{2} \mathrm{Cr}_{2} \mathrm{O}_{7}$ in a $2 \mathrm{M}$ solution of $\mathrm{H}_{2} \mathrm{SO}_{4}$ ) (Fig. 6), so-called 'wet oxidation', and pre-combustion of the sample in oxygen flow at $330^{\circ} \mathrm{C}$ and $630^{\circ} \mathrm{C}$, i.e. temperatures lower than the final combustion at $850^{\circ} \mathrm{C}$. BIRD et al. (1999) used these two methods and showed that the oldest ages of very old charcoal, i.e. the most effective removal of contamination can be obtained when 'wet oxidised' samples are also pre-combusted.

HatTÉ et al. (2001) proposed a replacement of the last hydrochloric wash of peat and paleosols (sediments rich in $\mathrm{Fe}$ ) by a wash with an oxidising agent such as $\mathrm{K}_{2} \mathrm{Cr}_{2} \mathrm{O}_{7}$. In this study, it was shown that the oxidation process breaks insoluble ferrous compounds that were formed during the alkali step, which could possibly incorporate modern $\mathrm{CO}_{2}$.

\subsubsection{Soxhlet treatment}

Samples originating from museums and private collections often have their own history of conservation. In most cases, records of restoration are sparse or non-existent. M aterials used as conservative substances contain carbon, which is either of modern or fossil origin and can contaminate samples. Naturally occurring samples can also be contaminated by fossil carbon. The effect has been observed in archaeological samples from Terqa, Syria where asphalt was present in the deposits. Some charcoal samples from this region were dated to be as old as 28,700 B P whereas the archaeological context 
was dated to $3000 \mathrm{BP}$ or younger (VenKateSAN et al. 1982). Therefore it is advisable to perform Soxhlet treatment of organic matter recovered from soils, sediments and any tar-containing environments.

For Soxhlet treatment, a standard procedure has been developed (BRUHN et al. 2001, HAJDAS et al. 2004c) and the most common conservative substances are removed in a sequence of solvents bathing (hexane, acetone and methanol). The sample is placed in the Soxhlet apparatus as shown in Fig. 7 and the liquid is brought to the boiling point. The condensate circulates in the Soxhlet for $30 \mathrm{~min}$ so that the sample is immersed in the clean hot solvent almost all the time. Contamination is removed with each spilling of the solvent through the siphon back to the heated bottle.

\subsubsection{Leaching surface of carbonate samples}

Surface of carbonate samples such as tufa, corals and shells may be contaminated due to diagenic processes. In order to remove such contamination, samples are cleaned mechanically (using an ultrasonic bath) and subjected to various leaching procedures, which involve acid and/or $\mathrm{H}_{2} \mathrm{O}_{2}$ solution. The degree of leaching varies, depending on the material dated. BURR et al. (1992) showed that $80 \%$ leaching of coral surfaces yields satisfactory ages. A ges of ostracode shells from sediments of $M$ ono $L$ ake became older as the shells were successively dissolved (Fig. 8) (HAJDAs et al. 2004d).

\subsubsection{Bone organic fraction}

Bone contains mainly mineralised hydroxylapatite and carbonate-apatite as well as partly fluorapatite and chlorapatite, which are bound to a matrix of collagen. Collagen makes up to $20 \%$ of dried, defatted fresh bone. A smaller fraction of the organic matrix is formed by non-collagen proteins such as osteocalcin or ferritin.

Most laboratories employ the method developed by LongIn (1971) (Fig. 9). Bones are first crushed or ground in a mill to speed up the dissolution in acid. This step removes contaminants but may remove collagen as well. Therefore, time and acid strength should be controlled during the process.

Gelatine is obtained by dissolution of collagen in a weak acid (LoNGIN 1971). The demineralised sample is placed in $0.01 \mathrm{~N} \mathrm{HCl}$ solution and left at 58 으 for $18-24 \mathrm{hr}$. The solution is then filtered and freeze-dried (Fig. 9) prior to combustion. In order to remove potential contamination of the bone, additional separation techniques have been developed. A modification of the LoNGIN (1971) method, including

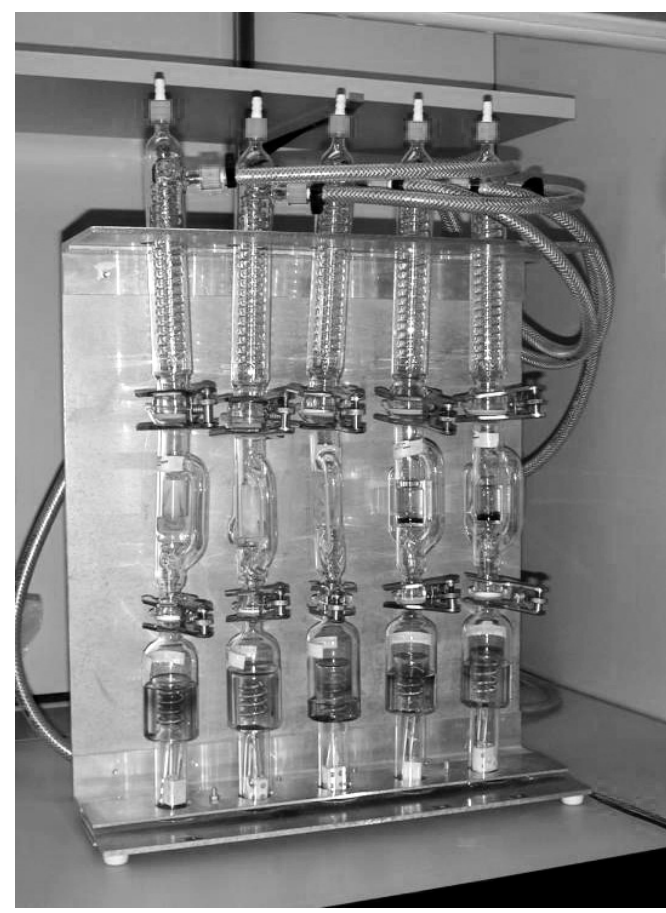

Fig. 7: Soxhlet preparation system at the ETH lab. The sample holders (middle part) are placed above a boiling solvent (lower part). The vapours of the solvent are cooled (upper part) and precipitated into the sample holder.

Abb. 7: Soxhlet Aufbereitungssystem im Labor der ETH. Die Probenhalter (mittlerer Teil) werden oberhalb eines kochenden Lösungsmittels platziert (unterer Teil). Der Dampf des Lösungsmittels wird gekühlt (oberer Teil) und schlägt sich im Probenhalter nieder. 


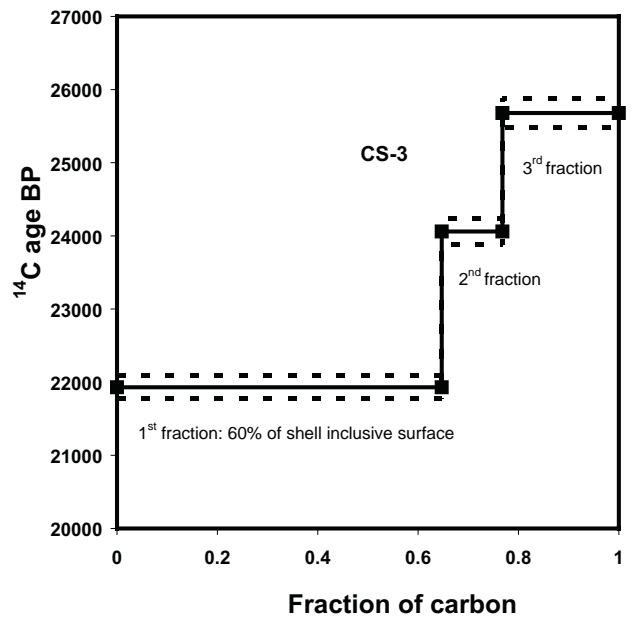

Fig. 8: Effect of consecutive leaching on radiocarbon age of ostracode shells from Carlson Sink, M ono Lake, USA (HajDAS et al. 2004d).

A bb. 8: Effekt des fortlaufenden A blaugens auf Radiokohlenstoffalter von 0 strakodenschalen aus $C$ arlson Sink, M ono Lake, USA (HajdAs et al. 2004d).

a short treatment of 'collagen' with a base solution prior to gelatinisation, has been proposed by Arslanov \& Svezhentsev (1993). This procedure was adopted by HAJDAS ET AL. (2007) and PIOtrowska \& GosLar (2002) and proved very effective in removing contamination. Separation of molecular masses by ultra-filtration was proposed by Brown et al. (1988) and improved providing very promising results (HIGHAM et al. 2006a, 2006b). The procedure of ultra-filtration involves separation of molecular masses because those of peptides are heavier than the possible contaminant of humic and fulvic acids. The liquid is placed in ultra-filtration tubes with a $30 \mathrm{kDa}$ filter (Viva Spin or M illipore) and centrifuged at $4000 \mathrm{rpm}$ for 15 to $30 \mathrm{~min}$ (depending on the volume of the tube). In effect, molecules heavier than $30 \mathrm{kD}$ a will remain above whereas the smaller (contamination fraction) will pass through the filter and be discarded. The heavier fraction obtained is freeze-dried and then subjected to combustion.

\section{Site and sample specific problems of radiocarbon dating}

In order to obtain the most accurate ages and reliable chronologies for the studied objects or sites (sedimentary records), appropriate material must be sampled for radiocarbon dating. For lake sediments, terrestrial macrofossils should be sampled to avoid potential 'hard water' effects caused by old carbonates built into organic matter of aquatic plants (HAJDAs et al. 1993, 1995, 1998). The presence of old carbon dissolved from bedrock is different from site to site and the 'hard water' effect may range from hundreds of years to nil. More locally, radiocarbon ages of organic matter can also be influenced due to volcanic $\left({ }^{14} \mathrm{C}\right.$ free) $\mathrm{CO}_{2}$ added to the atmosphere or dissolved in water. For example, remains of aquatic plants found in sediments of Lake Monticchio (Italy) were more than $10,000{ }^{14} \mathrm{C}$ yr older compared to terrestrial macrofossils in the same sediment layer (H Ajdas et al. 1998). A nother source of old carbon has been observed in polar regions where slow decomposition of organic matter and longevity of some species of mosses might result in older radiocarbon ages (H u m Lum et al. 2005). Similarly, too old ages are observed when redeposited or re-used material is dated. The best example is the 'old wood' effect known in dating wooden artefacts.

For marine records, hand picked foraminifer shells of plankton living in the upper layer of the ocean are usually used for dating. The radiocarbon age of water in this layer varies from 400 to $1200{ }^{14} \mathrm{C}$ yr. Correction for the marine reservoir effect is based on measurements of marine radiocarbon ages of material with known age (Reimer \& Reimer 2001). Other problems in dating marine records are related to bioturbation and poor preservation of shells as discussed by Broecker et al. (1999, 2006).

\section{Graphite preparation for $\mathrm{AMS}{ }^{14} \mathrm{C}$ mea- surements}

For AMS measurements of ${ }^{14} \mathrm{C} /{ }^{12} \mathrm{C}$ ratios, the autochthonous carbon present in the sample 
material has to be transformed into pure graphite. The first step in this process is obtaining $\mathrm{CO}_{2}$ by either combustion (organic matter) or acidification (shells and inorganic sediments). For combustion, dried organic matter is weighed and placed in a quartz glass tube, which contains wire-formed CuO for oxidation of the material that is sealed after the tube is evacuated. Silver wire or powder is added together with the sample to bind $\mathrm{SO}_{2}$ and other halogen gases that could poison the graphitisation reaction. The sealed tubes are placed in an oven at $950^{\circ} \mathrm{C}$ for $2 \mathrm{hr}$. Carbonate samples are placed in a special chamber, which is evacuated, then mixed with concentrated phosphoric acid and dissolved. The resulting $\mathrm{CO}_{2}$ is then purified and frozen using liquid nitrogen $\left(\mathrm{H}_{\mathrm{AJ}}\right.$ DAs et al. 2004d). The experimental details are given in HAJDAS et al. (2004c).

M ost of the A M S laboratories use the graphitisation method described by Vogel et al. (1984), where the reaction of $\mathrm{CO}_{2}+2 \mathrm{H}_{2}$ (heated to 580 to $600^{\circ} \mathrm{C}$ for ca. 2 to $4 \mathrm{hr}$ ) over catalyst (cobalt or iron powder) results in reduction to $C$ and $\mathrm{H}_{2} \mathrm{O}$. The graphite that forms on the surface of the catalyst is then pressed onto a target designed for A M S measurement.

M easurements of the ${ }^{14} \mathrm{C} /{ }^{12} \mathrm{C}$ and ${ }^{13} \mathrm{C} /{ }^{12} \mathrm{C}$ ratios of the samples to be dated are determined relative to the respective NBS oxalic acid I or oxalic acid II standard values. Chemistry blanks prepared from natural graphite, coal or marble (for example the C-1 standard of IAEA, Vienna) is usually analysed in order to determine contamination introduced during sample preparation. All samples (unknowns, standards and blanks) of one series are measured several times (typically three or four). The total measuring time per sample is around 30 to $40 \mathrm{~min}$. For details of measurements performed at the AMS facility at the ETH Zurich see BonANI et al. (1987) and SynAL et al. (1997, 2007).

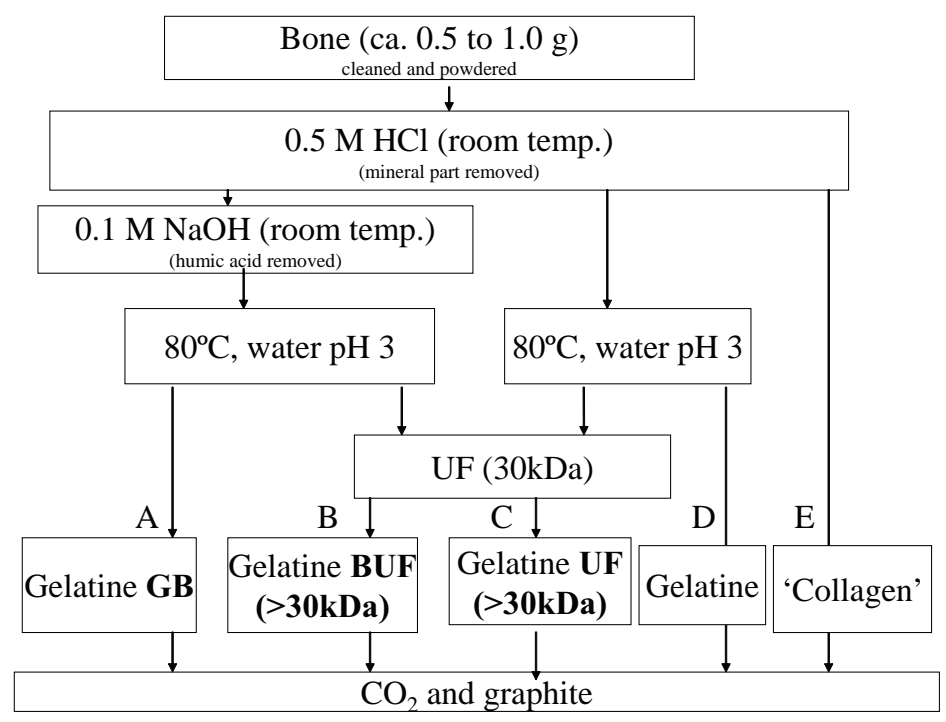

Fig. 9: Overview of bone treatment (organic fraction): path A: modified L ongin method (A RSLANov \& SVEZHENTSEV 1993), path B: modified L ongin method combined with Ultra Filtration, path C: L ongin method + Ultra-Filtration (Brown et al. 1988), path D: Longin method (L ongIN 1971), path E: 'collagen'.

A bb. 9: Überblick über der A ufbereitung von $\mathrm{K}$ nochen (organische Fraktion): Pfad A: modifiziertes Longin-Verfahren (Arslanov \& Svezhentsev 1993), Pfad B: modifiziertes Longin-Verfahren kombiniert mit Ultra-Filtration, Pfad C: Longin-Verfahren+UItra-Filtration (Brown et al. 1988), Pfad D: Longin-Verfahren (LongIn 1971), Pfad E: 'Kollagen'. 


\section{Calibration issues}

\section{1 ${ }^{14} \mathrm{C}$ age 'plateaux', rapid 'jumps' and 'wiggles'}

Precise radiocarbon dating of certain periods of interest may be complicated by extreme variability of atmospheric ${ }^{14} \mathrm{C}$ content present at times in the radiocarbon calibration curve. These complications arise from variations in atmospheric ${ }^{14} \mathrm{C}$ content caused by the changes in the production rate and changes in the carbon cycle and are known as 'wiggles' in the calibration curve. Radiocarbon age ' plateaux', for example, caused by a decrease in the atmospheric ${ }^{14} \mathrm{C}$ concentration, appears as a slowing down of the ${ }^{14} \mathrm{C}$ clock such as one that occurred at 2500-2400 $B P$, i.e. between $700 \mathrm{BC}$ and $400 \mathrm{BC}$ ('Hallstatt plateau') (Fig. 10). In effect, similar radiocarbon ages may appear to correspond to a range of up to 500 cal endar years. The opposite is observed when atmospheric ${ }^{14} \mathrm{C}$ levels increase so that the ${ }^{14} \mathrm{C}$ clock appears to speed up. Therefore, due

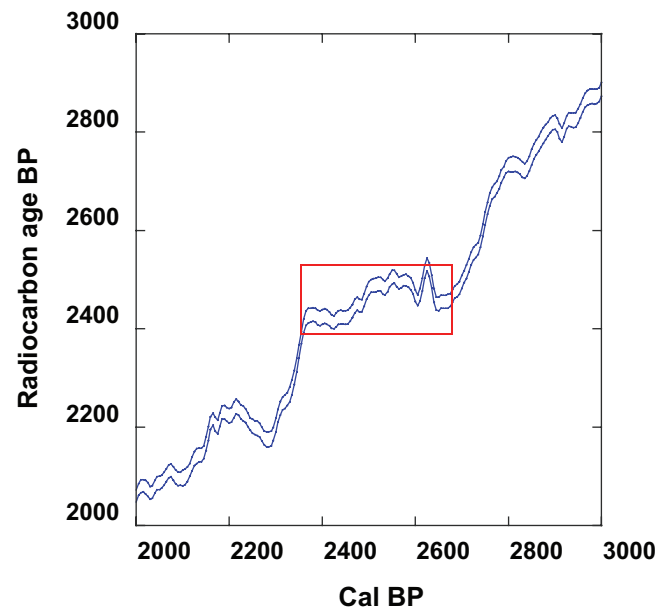

Fig. 10: Radiocarbon age plateau at 2400-2500 BP ( $700 \mathrm{BC}$ and $400 \mathrm{BC}$ ) known as a 'H allstatt plateau' marked on the calibration curve of INTCAL 04 (REIMER et al. 2004a).

A bb. 10: Radiokohlenstoff Altersplateau zwischen 2400 und $2500 \mathrm{BP}$ ( $700 \mathrm{BC}$ bis $400 \mathrm{BC}$ ), bekannt als "H allstatt Plateau", markiert auf der Kalibrierungskurve INTCA L 04 (REIMER et al. 2004a). to the 'wiggles', a single radiocarbon age may correspond to more than one calendar age range or the ${ }^{14} \mathrm{C}$ clock may even appear to be reversed with respect to actual time.

The set of radiocarbon ages obtained on a trunk of a larch tree found in Scythian tombs/kurgans of A Itai M ountains illustrates the effect the age plateaus can have on the precision of calendar ages and shows how the wiggle match can help to resolve it. Eleven out of sixteen calibrated ages fall on the 2400-2500 BP age plateau. In effect, the calibrated ages of all these samples range from $700 \mathrm{BC}$ to $400 \mathrm{BC}$ (Fig. 11). However, a $\chi^{2}$ fit of the age sequence to the calibration curve resulted in a precise dating of the last ring to be $2267^{+13} /_{-21}$ cal BP $\left(317^{+13} /_{-21}\right.$ BC) (Fig. 12), which was presumably the year when the kurgan was built (H AJdAs et al. 2004b).

A nother method to improve calendar chronologies, despite the ${ }^{14} \mathrm{C}$ plateaux, is the use of models such as wiggle-matching or calibration models, where additional information about the samples (sequence order) might be applied to reduce the intervals of calibrated ages (RAM SEY et al. 2001). This B ayesian approach to calibration of radiocarbon ages (Buck et al. 1996) is now included in calibration programs such as BCal (http://bcal.sheffield.ac.uk) (Buck et al. 1999), OxCal (RAMSEY 2008) or B peat (BLAAuW $\&$ ChRISTEN 2005). 'Wiggle-matching' with the Bpeat program has been applied to develop age-depth models of Holocene peat sections from the Netherlands (B LAAuw et al. 2007). The high-resolution radiocarbon dating combined with Bayesian modelling was used to establish chronology of climatic events of Kaipo Bog (New Zealand) (Hajdas et al. 2006). Similarly, the late Glacial sedimentary record of $\mathrm{H}$ auterive/ R ouges-Terres, Lake N euchâtel ( $\mathrm{CH}$ ) ( $\mathrm{H}_{\mathrm{AJ}} \mathrm{DAs}$ s et al. 2004a) were radiocarbon dated and the age model was built using B ayesian model of $\mathrm{OxCal}$ v3 program (RAM SEY 2001).

\subsection{Extension of the calibration curve}

The history of variations in atmospheric ${ }^{14} \mathrm{C}$ production during the last 12,400 years is based on tree ring measurements and dendrochronol- 


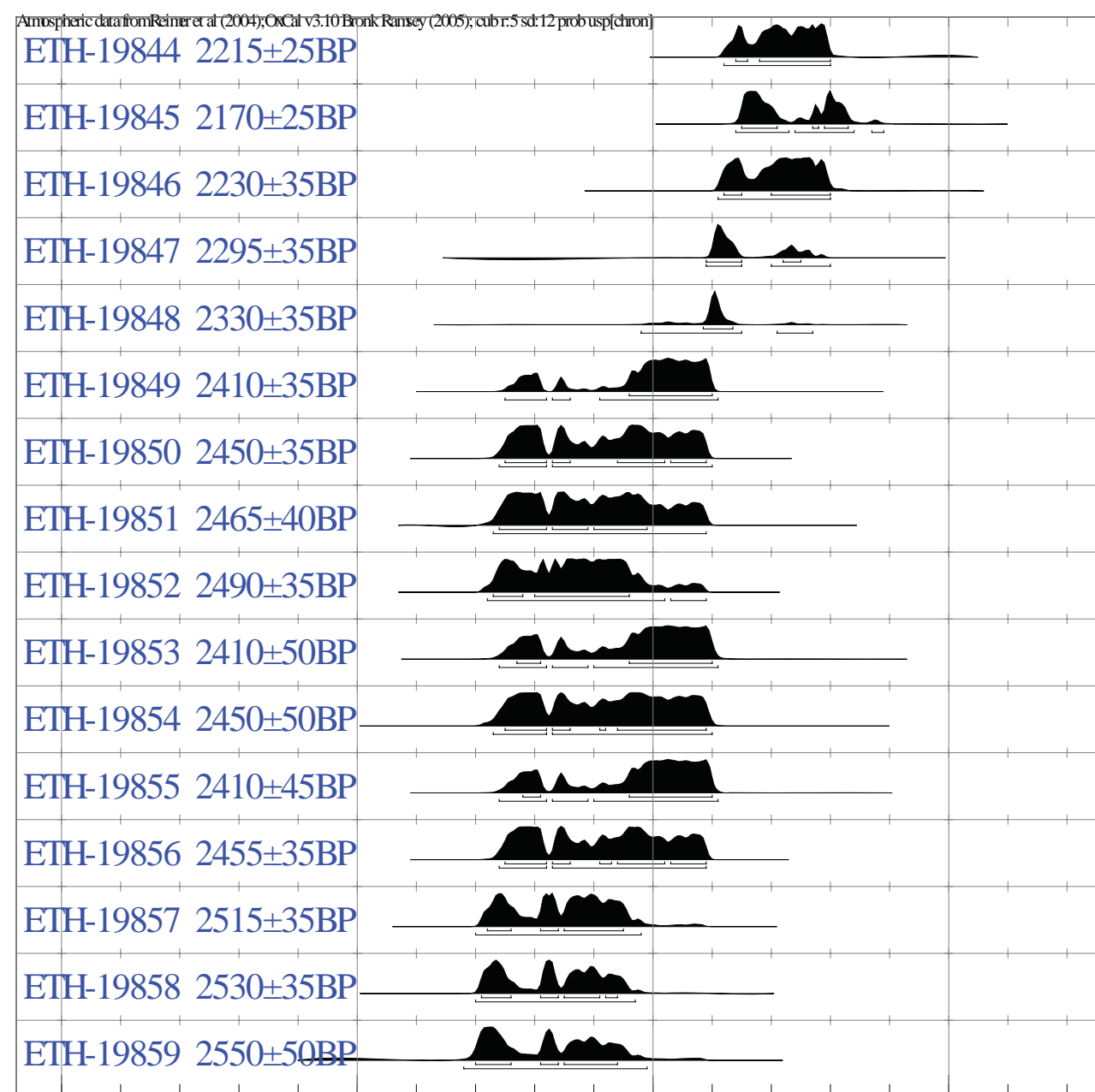

\section{CalBC}

\section{Calibrated date}

Fig. 11: Results of calibration of radiocarbon ages obtained for a tree ring sequence of samples from a larch tree recovered from a kurgan (burial mound) in Ulandryk (A Itai M ountains) (HAJDAs et al. 2004b). N ote the wide ranges of calibrated age intervals obtained for radiocarbon ages hitting the plateau (see text). A n exception is the sample ETH-19848, $2330 \pm 35$ BP, as this age corresponds to a steep slope on the calibration curve

A bb. 11: E rgebnisse der $\mathrm{K}$ al ibrierung von Radiokohlenstoffaltern für Proben aus einer B aumringsequenz aus einer Lärche, die aus einem K urgan (Grabhügel) aus U landryk (Altai G ebirge) geborgen wurde (HAJDAs et al. 2004b). B emerkenswert ist der breite B ereich an kalibrierten A Itersintervallen für Radiokohlenstoffaltern, die auf Plateaus liegen (siehe Text). Eine A usnahme ist Probe ETH-19848, $2330 \pm 35$ B P, weil diese Probe mit einem steilen $\mathrm{A}$ bfall in der K alibrationskurve zusammenfällt. 


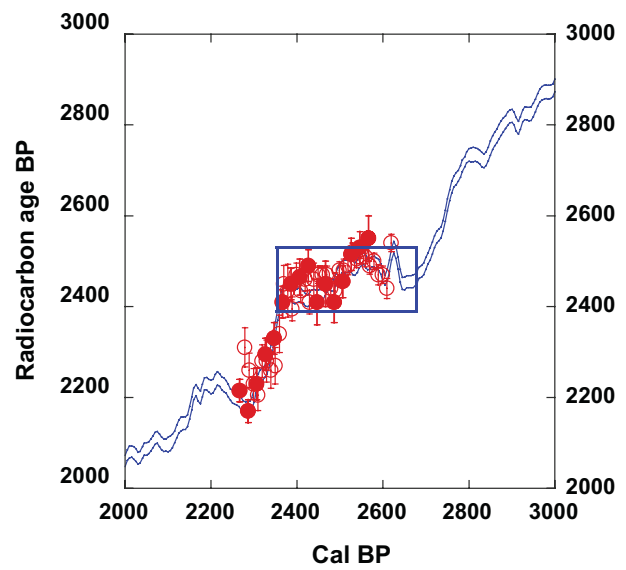

Fig. 12: R esults from the Ulandryk kurgan (Fig. 11) fitted to the calibration curve (see text): filled circles (HAJDAs et al. 2004b) and open circles (K UZMIN et al. 2004). The last ring is dated to $2267^{+13} /_{-21}$ cal BP $\left(317^{+13} /_{-21} \mathrm{BC}\right)$.

A bb. 12: Ergebnisse für den Ulandryk K urgan (A bb. 11) projiziert auf die Kalibrierungskurve (siehe Text): ausgefüllte Kreise (HAJDAs et al. 2004b) und offene $K$ reise (K Uzm In et al. 2004). Der letzte Ring wurde auf $2267+13]_{-21}$ cal BP $\left(317+13 /{ }_{-21}\right.$ BC $)$ datiert.

ogy. However, the older part of the calibration has to be based on records other than the trees. The radiocarbon ages of foraminifera shells from sediments of Cariaco B asin and measurements of ${ }^{14} \mathrm{C}$ on $\mathrm{U} / \mathrm{Th}$ dated corals, all corrected for corresponding local reservoir age, have been used to construct the late glacial and glacial part of the calibration curve $(12,400$ 26,000 cal BP) (Reimer et al. 2004b) (Fig. 13). In addition to the atmospheric calibration curve, a global mix layer marine reservoir age has been modelled and used for construction of a marine calibration (HUGHEN et al. 2004b).

Extension of the calibration curve to the limits of the radiocarbon method is of great interest to the wide range of palaeoclimate studies and archaeological research. Corals, marine and lake sediments and stalagmites may provide continuous records of ${ }^{14} \mathrm{C}$ changes (Fig. 14). In addition, $\mathrm{M}$ arine Isotope Stage $3 \mathrm{~K}$ auri wood found in bogs of New Zealand is being studied for this purpose (Hog et al. 2007, TURney et al. 2007). In the future, an updated data set of INTCA L 04 will allow conversion of radiocarbon ages older than $21000 \mathrm{BP}$ to the estimated (not yet calibrated) calendar ages (RAMSEY et al. 2006).

A nother problem of the calibration curve that must be considered is the reconstruction of the temporal as well as spatial variations of the marine reservoir effect. Variations documented for specific locations and periods (for summary see ReIMer \& ReIMer 2001) may affect radiocarbon-based chronologies of the marine records. Efforts are being made to reconstruct such variations using high-resolution chronologies of marine records (BONDEVIK et al. 1999, 2001, 2006; M ANGERUD et al. 2006) or to model it (FrANKE et al. 2008).

\section{Summary and outlook}

A s long as carbon-bearing material is available, radiocarbon dating methodsallow measurement of the isotopic composition of the material, which is only limited to the materials formed during the last 50-55 ka. The measured ${ }^{14} \mathrm{C} /{ }^{12} \mathrm{C}$ ratio relative to the reference material allows calculation of the radiocarbon age. However, due to the complicated history of ${ }^{14} \mathrm{C}$, this age requires translation to the calendar age.

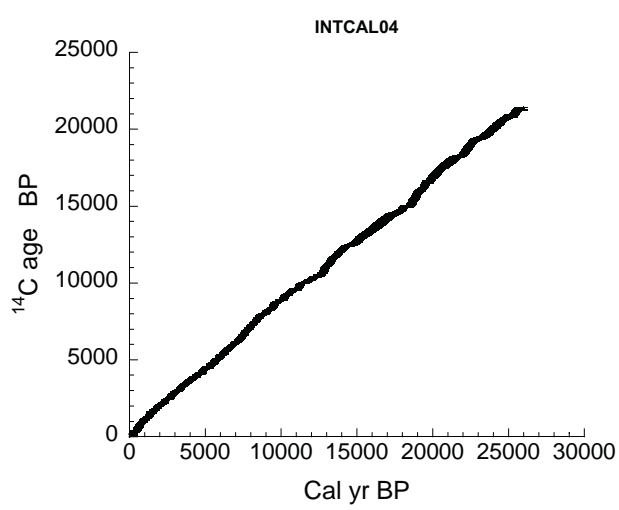

Fig. 13: Radiocarbon calibration curve of INCAL 04 (Reimer et al. 2004a).

A bb. 13: Radiokohlenstoff-K al ibrierungskurve INTCA L 04 (Reimer et al. 2004a). 


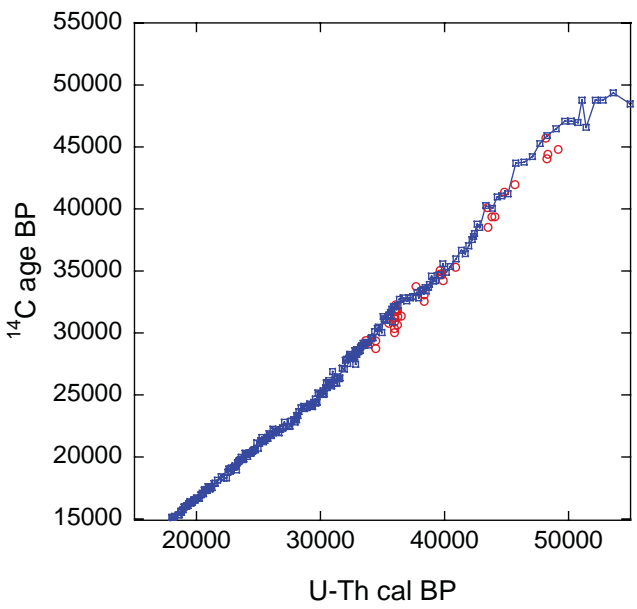

Fig. 14: Reconstruction of past variation in ${ }^{14} \mathrm{C}$ content based on measurements of foraminifera (squares) from Cariaco Basin; with the calendar time scale obtained by climatic correlation to U/Th dated stalagmites from the Hulu Cave (Hughen et al. 2006; WANG et al. 2001). Included are also corals ages (circles) dated by both radiocarbon and U/Th (FAIRBANKS et al. 2005).

Abb. 14: Rekonstruktion vergangener Variationen im ${ }^{14} \mathrm{C}$ Gehalt basierend auf M essungen von Foraminiferen (Vierecke) aus dem Cariaco Becken, die durch $\mathrm{K}$ limatische Proxy mit der K alender-Zeitreihe U/Th-datierter Stalagmiten aus der Hulu Cave korreliert wurden (HUGHEN et al. 2006; WANG et al. 2001) und Korallen (K reise). Zudem sind Korallenalter enthalten, die sowohl durch Radiokohlenstoff als auch U/Th datiert wurden (FAIRBANKS et al. 2005).

Sampling and sample preparation are important steps in obtaining reliable radiocarbon ages. M easurements and error analysis, corrections for fractionation and reservoir effect are the next steps that are followed by the calibration of the radiocarbon age. From the very beginning of the method, all these components have been under constant development. Improved preparation techniques allow the selection of material free of contamination that is most suitable for dating. Twenty-five years ago, the development of the AMS revolutionised radiocarbon dating allowing for analyses on samples containing only a few mg of carbon (as compared to grams needed for conventional radiocarbon dating method). Calibration issues were also recognised and great efforts of many international groups resulted in the calibration curves that are presently in use. This work is being continued and remains a great challenge to the radiocarbon dating community.

During the last ten years, novel solutions in the AMS technique resulted in lowering energies needed for successful separation of $C$ isotopes. Radiocarbon-dating dedicated small AM S setups are becoming a reality, allowing for higher throughput and shorter turnaround time of samples (Suter et al. 2007; Synal et al. 2007). Moreover, sophisticated preparative methods allow for separation of carbon at the molecular level (e.g., EgLINTON et al. 1996, Ingallis et al. 2004, Von REDEN et al. 1998), providing opportunity for tracing contamination. The A M S systems that operate with a gas ion source allow measurements to be performed on $\mathrm{CO}_{2}$ (Ruff et al. 2007). Samples containing few micrograms of $\mathrm{C}$ are combusted and their isotopic composition is measured without the graphitisation step involved. This technical development marks another revolution in radiocarbon dating that will allow radiocarbon dating at the molecular level. Thanks to this development, the great value of ${ }^{14} \mathrm{C}$ as an environmental tracer is becoming very appealing in addition to its usefulness as a dating tool.

\section{Acknowledgments}

Special thanks to all the colleagues from the AMS facility at ETH Zurich for support of my ${ }^{14} \mathrm{C}$ research of the last 20 years. Liping Zhou and A nne Hormes provided very helpful reviews of this manuscript.

\section{References}

Arnold, J. R. \& Libiy, W. F. (1949): A ge Determinations by Radiocarbon Content - Checks with Samples of Known Age. - Science, 110: 678-680.

Arslanov, K. A. \& Svezhentsev, Y. S. (1993): An Improved M ethod for Radiocarbon Dating Fossil Bones. - Radiocarbon, 35: 387-391. 
Beer, J., Siegenthaler, U., Bonani, G., Finkel, R. C., Oeschger, H., Suter, M. \& Wolfli, W. (1988): Information on Past Solar-Activity and Geomagnetism from Be-10 in the Camp Century Ice Core. - Nature, 331: 675-679.

Bird ,M. I., Ayliffe, L. K., Fifield, L. K., Turney, C.S.M., Cresswell. R.G., Barrows. T. T. \& DAVID. B. (1999): Radiocarbon dating of "old" charcoal using a w et oxidation, stepped-combustion procedure. - Radiocarbon. 41: 127-140.

Blaauw, M., Bakker, R., Christen, J.A., Hall, V.A. \& VAN deR PLICHT, J. (2007): A Bayesian framework for age modeling of radiocarbon-dated peat deposits: Case studies from the Netherlands. - Radiocarbon, 49: 357-367.

BlaAuw, M. \& Christen, J.A. (2005): Radiocarbon peat chronologies and environmental change. -Journal of the Royal Statistical Society Series C-A pplied Statistics, 54: 805-816.

Bonani, G., Beer, J., Hofmann, H., Synal, H. A., Suter, M., Wölfli, W., Pfleiderer, C., JungHANS, C.\& M ÜNNICH, K.O. (1987): Fractionation, precision and accuracy in ${ }^{14} \mathrm{C}$ and ${ }^{13} \mathrm{C}$ measurements. - Nuclear Instruments and $\mathrm{M}$ ethods in Physics Research, B 29: 87-90.

Bondevik, S., Birks, H.H., Gulliksen, S. \& ManGERUD, J. (1999): Late Weichselian marine C-14 reservoir ages at the western coast of Norway. - Q uaternary R esearch, 52: 104-114.

B ONDEVIK, S., M ANGERUd, J., Birks, H.H., GULliksen, S. \& ReImer, P. (2006): Changes in N orth A tlantic Radiocarbon Reservoir A ges During the Allerød and Younger Dryas. - Science, 312: 1514-1517.

B ONdeVik, S., M ANGerud, J. \& Gulliksen, S. (2001): The marine C-14 age of the Vedde Ash Bed along the west coast of Norway. - Journal of Quaternary Science, 16: 3-7.

Broecker, W., Barker, S., Clark, E., Hajdas, I. \& B ONANI, G. (2006): A nomal ous radiocarbon ages for foraminifera shells. - Paleoceanography 21: PA 2008, doi:10.1029/2005PA 001212.

Broecker, W., Matsumoto, K., Clark, E., Hajdas, I. \& BONANI, G. (1999): Radiocarbon age differences between coexisting foraminiferal species. - Pal eoceanography, 14: 431-436.

Brown, T. A., Nelson, D.E., Vogel, J.S. \& Southon, J.R. (1988): Improved Collagen Extraction by Modified Longin Method. - Radiocarbon, 30: 171-177.

Bruhn, F., Duhr, A., Grootes, P.M., Mintrop, A. \& NAdeAu, M.J. (2001): Chemical removal of conservation substances by 'soxhlet'-type extraction. - Radiocarbon, 43: 229-237.
Buck, C.E., Christen, J.A. \& James, G.N. (1999) BCal: an on-line Bayesian radiocarbon calibration tool. - Internet Archaeology 7: http: //intarch.ac.uk/journal/issue7/buck/.

Buck, C.E., Cavanagh, W.G. \& Litton, C.D. (1996): The $B$ ayesian A pproach to Interpreting A rchaeological Data. - 377 S.; Chichester (Wiley).

Burr, G.S., Edwards, R.L., Donahue, D.J ., Druffel, E.R.M. \& TAYLOR, F.W. (1992): M ass-Spectrometric C-14 and U-Th M easurements in Coral. - Radiocarbon, 34: 611-618.

Channell, J.E.T., Stoner , J.S., Hodell, D.A. \& ChARLES, C.D. (2000): Geomagnetic paleointensity for the last 100 kyr from the sub-antarctic South A tlantic: A tool for inter-hemispheric correlation. - Earth and Planetary Science Letters, 175: 145-160.

Craig, H. (1953): The Geochemistry of the Stable Carbon Isotopes. - Geochimica Et Cosmochimica A cta, 3: 53-92.

Craig, H. (1954): Carbon-13 in Plants and the Relationships between Carbon-13 and Carbon-14 Variations in Nature. - Journal of Geology, 62: 115-149.

de VRies, H.L. \& Barendsen, G.W. (1954): M easurements of $A$ ge by the Carbon-14 Technique. - Nature, 174: 1138-1141.

Elington, T.I, Aluwihare L.I., Bauer J.E., Druffel E.R.M. \& M M NICHOL, A.P. (1996): Gas chromatographic isolation of individual compounds from complex matrices for radiocarbon dating. - A nalytical Chemistry 68: 904-912.

Fairbanks, R.G., Mortlock, R.A., Chiu, T.-C., Cao, L., Kaplan, A., Guilderson, T.P., Fairbanks, T.W., Bloom, A.L., Grootes, P.M \& \& Nadeau, M.-J. (2005): Radiocarbon calibration curve spanning 0 to 50,000 years BP based on paired 230Th/234U/238U and 14C dates on pristine corals. - Quaternary Science Reviews, 24: 1781-1796.

Finkel, R.C. \& Suter, M . (1993): A M S in the Earth Sciences:Technique and Applications. - Advances in A nalytical G eochemistry, 1: 1-114.

Franke, J., Paul, A. \& Schulz, M . (2008): M odeling variations of marine reservoir ages during the last 45000 years. - Climate of the Past Discussions, 4: 81-110.

Godwin, H. (1962): Half-Life of Radiocarbon. - Nature, 195: 984

H AJDAS, I. (1993): Extension of the radiocarbon calibration curve by AM S dating of laminated sediments of lake Soppensee and lake Holzmaar. - Diss. ETH Nr.10157 thesis: 147 S.; ETH Zurich. 
Hajdas, I., Ivy, S.D., Beer, J., B Onani, G., I mboden, D., Lotter, A .F., Sturm, M . \& Suter, M . (1993): A ms Radiocarbon Dating and Varve Chronology of Lake Soppensee - 6000 to 12000 C-14 Years BP. - Climate Dynamics, 9: 107-116.

Hajdas, I., ZolitschKa, B., IVy-ochs, S.D., Beer, J., Bonani, G., Leroy, S.A.G., Negendank, J.W., Ramrath, M.\& Suter, M. (1995): Ams Radiocarbon Dating of A nnually L aminated Sediments from L ake H olzmaar, Germany. - Quaternary Science R eviews, 14: 137-143.

Hajdas, I., Bonani, G., Zolitschka, B., Brauer, A. $\&$ Negendank, J.W. (1998): C-14 ages of terrestrial macrofossils from Lago Grande di M onticchio (Italy). - Radiocarbon, 40: 803-808.

Hajdas, I., Bonani, G., Hadorn, P., Thew, N., Coope, G.R. \& LEMDAHL, G. (2004a): Radiocarbon and absolute chronology of the Late-Glacial record from Hauterive/R ouges-Terres, Lake Neuchatel (CH). - Nuclear Instruments and Methods in Physics Research Section B: B eam Interactions with $M$ aterials and A toms, 223-224: 308-312.

Hajdas, I., Bonani, G., Slusarenko, I.Y. \& Seifert, M. (2004b): Chronology of Pazyryk 2 and Ulandryk $4 \mathrm{~K}$ ugrans based on high resolution radiocarbon dating and dendrochronology -a step towards precise dating of Scythian Burials. - In: Scott, E.M. (ed.): I mpact of the Environment on the Human M igration in Eurasia: 107-116; Printed in the N etherlands (K luwer A cademic Publishers).

Hajdas, I., Bonani, G., Thut, J., Leone, G., PfenNINGER, R. \& M ADEN, C. (2004C): A report on sample preparation at the ETH/PSI A M S facility in Zurich. - N uclear Instruments and $M$ ethods in Physics Research Section B: B eam Interactions with $M$ aterials and $A$ toms, 223-224: 267-271.

Hajdas, I., Bonani, G., Zimmerman, S.H., MendelSON, M.\& Hemming, S. (2004d): C-14 ages of ostracodes from pleistocene lake sediments of the western Great Basin, USA-Results of progressive acid leaching. - Radiocarbon, 46: 189-200.

Hajdas, I., Lowe, D.J ., Newnham, R.M . \& Bonani, G. (2006): Timing of the late-glacial climate reversal in the Southern Hemisphere using high-resolution radiocarbon chronology for K aipo bog, N ew Zealand. - Quaternary R esearch, 65: 340-345.

Hajdas, I., Bonani, G., Furrer, H., Mader, A.\& SCHOCH, W. (2007): Radiocarbon chronology of the mammoth site at Niederweningen, Switzerland: Results from dating bones, teeth, wood, and peat. - Quaternary International, 164-65: 98-105.
Hatté, C., Morvan, J., Noury, C. \& Paterne, M. (2001): Is classical acid-alkali-acid treatment responsible for contamination? An alternative proposition. - Radiocarbon, 43: 177-182.

HeAd, M.J. \& Zhou, W. J. (2000): Evaluation of $\mathrm{NaOH}$ leaching techniques to extract humic acids from palaeosols. - Nuclear Instruments \& $M$ ethods in Physics Research Section B-B eam Interactions with Materials and Atoms, 172: 434-439.

Higham, T., Ramsey, C.B., Karavanic, I., Smith, F.H. \& Trinkaus, E. (2006a): Revised direct radiocarbon dating of the Vindija $G(1)$ upper Paleolithic Neandertals. - Proceedings of the National Academy of Sciences of the United States of A merica, 103: 553-557.

Higham, T.F.G., Jacobi, R.M. \& Ramsey, C.B. (2006b): AMS radiocarbon dating of ancient bone using ultrafiltration. - Radiocarbon, 48: 179-195.

Hogg, A.G., Fifield, L.K., Turney, C.S.M., Palmer, J.G., Galbraith, R. \& Baillie, M.G.K. (2006): Dating ancient wood by high-sensitivity liquid scintillation counting and accel erator mass spectrometry - Pushing the boundaries. - Q uaternary Geochronology, 1: 241-248.

Hogg, A. G., Fifield, L.K., Palmer, J.G., Turney, C.S.M. \& GALBRAITH, R. (2007): Robust radiocarbon dating of wood samples by high-sensitivity liquid scintillation spectroscopy in the 50-70 kyr age range. - Radiocarbon, 49: 379-391.

HuA, Q. \& BarbetTI, M. (2004): Review of tropospheric bomb C-14 data for carbon cycle modeling and age calibration purposes. - Radiocarbon 46: 1273-1298.

Hughen, K., Lehman S., Southon J., Overpeck J., Marchal O., Herring C.\& Turnbull J. (2004a): C-14 activity and global carbon cycle changes over the past 50,000 years. - Science 303: 202-207.

Hughen, K.A., Baillie, M.G.L., Bard, E., Beck, J.W., Bertrand, C.J.H., Blackwell, P.G., Buck, C.E., Burr, G.S., Cutler, K.B., Damon, P.E., Edwards, R.L., Fairbanks, R.G., Friedrich, M., Guilderson, T.P., Kromer, B., McCormac, G., Manning, S., Ramsey, C.B., Reimer, P.J ., Reimer, R.W., Remmele, S., Southon, J.R., Stuiver, M., Talamo, S., Taylor, F.W., van der Plicht, J. \& Wey henmeyer, C.E. (2004b): Marine04 marine radiocarbon age calibration, 0-26 cal kyr BP. - Radiocarbon, 46: 1059-1086.

Hughen, K., Southon, J., Lehman, S., Bertrand, C. \& Turnbull, J. (2006): Marine-derived C- 
14 calibration and activity record for the past 50,000 years updated from the Cariaco Basin. - Quaternary Science Reviews, 25: 3216-3227.

Humlum O., Elberling B., Hormes A ., Fjordheim K., Hansen O. H. \& Heinemeier J. (2005): Late-Holocene glacier growth in Svalbard, documented by subglacial relict vegetation and living soil microbes. - Holocene 15: 396-407.

Ingalls, A.E., Anderson, R.F. \& Pearson, A . (2004): Radiocarbon dating of diatom-bound organic compounds.-M arine Chemistry, 92: 91-105.

J ULL, A.J.T. \& BURR, G. S. (2006): A ccelerator mass spectrometry: Is the future bigger or smaller? - Earth and Planetary Science Letters, 243: 305-325.

KROMER B. \& M ÜNNich O. (1992): $\mathrm{CO}_{2}$ gas proportional counting in radiocarbon dating--review and perspective. In: TAYLOR, R.E., LONG, A.\& K RA, R.S. (eds) Radiocarbon after four decades. A $n$ interdisciplinary perspective: 184-197; N ew York (Springer Verlag)

Kuzmin, Y.V., Slusarenko, I.Y., Hajdas, I., Bonani, G. \& ChRISTEN, J.A. (2004): The comparison of C-14 wiggle-matching results for the 'floating' tree-ring chronology of the Ulandryk-4 burial ground (A Itai mountains, Siberia). - Radiocarbon, 46: 943-948.

Laj, C., Kissel, C., Mazaud, A., Channell, J.E.T. \& BeER, J. (2000): N orth A tlantic palaeointensity stack since $75 \mathrm{ka}$ (NAPIS-75) and the duration of the Laschamp event. - Philosophical Transactions of the Royal Society of London Series a-M athematical Physical and Engineering Sciences, 358: 1009-1025.

Laj, C., Kissel, C., Scao, V., Beer, J., Thomas, D.M., Guillou, H., Muscheler, R. \& Wagner, G. (2002): Geomagnetic intensity and inclination Variations at Hawaii for the past $98 \mathrm{kyr}$ from core SOH-4 (Big Island): a new study and a comparison with existing contemporary data. - Physics of the Earth and Planetary Interiors, 129: 205-243.

Levin, I., Hammer, S., Kromer, B. \& Meinhardt, F. (2008): Radiocarbon observations in atmospheric CO2: Determining fossil fuel $\mathrm{CO}_{2}$ over Europe using Jungfraujoch observations as background. - Science of The Total Environment, 391: 211-216.

LeVin, I. \& Hesshaimer, V. (2000): Radiocarbon - A unique tracer of global carbon cycle dynamics. - Radiocarbon, 42: 69-80.

LeVIN, I. \& KROMer, B. (2004): The tropospheric (CO2)-C-14 level in mid-latitudes of the $\mathrm{N}$ orth- ern Hemisphere (1959-2003). - Radiocarbon, 46: 1261-1272.

LibBy, W.F., A nderson, E.C.\& A Rnold, J.R. (1949): A ge Determination by Radiocarbon Content - World-Wide A ssay of Natural Radiocarbon. - Science, 109: 227-228.

LoNGIN, R. (1971): New Method of Collagen Extraction for Radiocarbon Dating. - N ature, 230: 241-242.

Mangerud, J., Bondevik, S., Gulliksen, S., Karin Hufthammer, A \& \& Hoisaeter, T. (2006): M arine $14 C$ reservoir ages for 19th century whales and molluscs from the N orth A tlantic. - Q uaternary Science Reviews, Critical Quaternary Stratigraphy, 25: 3228-3245.

M ANN, W.B. (1983): A n International R eference M aterial for Radiocarbon Dating. - Radiocarbon, 25: 519-527.

MASARIK, J. \& BEER, J. (1999): Simulation of particle fluxes and cosmogenic nuclide production in the Earth's atmosphere. - Journal of Geophysical Research, 104: 12099-12111.

McCormac, F.G., Hogg, A.G., Blackwell, P.G., Buck, C.E., Higham, T.F.G. \& Reimer, P.J. (2004): SHCal04 Southern Hemisphere calibration, 0-11.0 cal kyr BP. - Radiocarbon, 46: 1087-1092.

Mook, W.G. \& van der Plicht, J. (1999): Reporting C-14 activities and concentrations. - Radiocarbon, 41: 227-239.

Naysmith, P., Scott, E.M., Cook, G.T., Heinemeier, J., van der Plicht, J., Van Strydonck, M., Ramsey, C.B., Grootes, P.M \& \& Freeman, S.P.H.T. (2007): A cremated bone intercomparison study. - Radiocarbon, 49: 403-408.

Nydal, R., Gulliksen, S., L ovseth, K. \& Skogseth, F.H. (1984): Bomb C-14 in the Ocean Surface 1966-1981. - Radiocarbon, 26: 7-45.

NYDAL, R. \& LOVSETH, K. (1965): Distribution of Radiocarbon from Nuclear Tests. - N ature, 206: 1029.

NydaL, R. \& Lovseth, K. (1983): Tracing Bomb C-14 in the Atmosphere 1962-1980. - Journal of Geophysical Research-Oceans and A tmospheres, 88: 3621-3642.

Nydal, R., Lovseth, K. \& Skogseth, F.H. (1980): Transfer of Bomb C-14 to the Ocean Surface. - Radiocarbon, 22: 626-635.

Olsson, I. U., Karlen, I. \& Stenberg, A. (1966): Radiocarbon Variations in A tmosphere. - TelIus, 18: 293.

Paterne, M., Ayliffe, L.K., Arnold, M., Cabioch, G., Tisnerat-Laborde, N., Hatte, C., Douville, 
E. \& BARD, E. (2004): Paired C-14 and Th-230/ $U$ dating of surface corals from the $M$ arquesas and Vanuatu (sub-equatorial Pacific) in the 3000 to 15,000 cal yr interval. - Radiocarbon, 46: 551-566.

Pawelczyk, S. \& Pazdur, A. (2004): Carbon. isotopic composition of tree rings as a tool for biomonitoring CO2 level. - Radiocarbon, 46: 701-719.

Piotrowska, N. \& Goslar, T. (2002): Preparation of bone samples in the Gliwice radiocarbon laboratory for AMS radiocarbon dating. - Isotopes in Environmental and Health Studies, 38: 267-275.

RAMSEY, C.B. (2001): Development of the radiocarbon calibration program. - Radiocarbon, 43: 355-363.

Ramsey, C.B., Buck, C.E., Manning, S. W., Reimer, P. \& VAn der Plicht, H. (2006): Developments in radiocarbon calibration for archaeology. - A ntiquity, 80: 783-798.

Ramsey, C.B., van der Plicht, J. \& Weninger, B. (2001): 'Wiggle matching' radiocarbon dates. - Radiocarbon, 43: 381-389.

RAM SEY, C.B. (2008): Deposition models for chronological records. - Quaternary Science Reviews, 27: 42-60.

Reimer, P.J., Baillie, M.G.L., Bard, E., Bayliss, A., Beck, J.W., Bertrand, C.J.H., Blackwell, P.G. \& Buck, C.E. (2004a): IntCal04 Terrestrial Radiocarbon A ge Calibration, 0-26 Cal K yr BP. - Radiocarbon, 46: 1029-1058.

Reimer, P.J ., Baillie, M.G.L., Bard, E., Bayliss, A., Beck, J.W., Bertrand, C.J.H., Blackwell, P.G., Buck, C.E., Burr, G.S., Cutler, K.B., Damon, P.E., Edwards, R.L., Fairbanks, R.G., FriedRich, M., GuILderson, T.P., Hogg, A .G., Hughen, K.A., Kromer, B., McCormac, G., Manning, S., Ramsey, C.B., Reimer, R.W., Remmele, S., Southon, J.R., Stuiver, M., Talamo, S., Taylor, F.W., van der Plicht, J. \& Weyhenmeyer, C.E. (2004b): IntCal04 terrestrial radiocarbon age calibration, 0-26 cal kyr BP. - Radiocarbon, 46: 1029-1058.

Reimer, P.J., Brown, T.A. \& Reimer, R.W. (2004C): Discussion: Reporting and calibration of postbomb C-14 data. - Radiocarbon, 46: 1299-1304.

Reimer, P.J . \& ReImer, R.W. (2001): A marine reservoir correction database and on-line interface. - Radiocarbon, 43: 461-463.

Rom, W., Brenninkmeijer, C.A.M., Ramsey, C.B., Kutschera, W., Priller, A., Puchegger, S., Rockmann, T. \& Steier, P. (2000): M ethodologi- cal aspects of atmospheric (CO)-C-14 measurements with A M S. - Nucl ear Instruments \& M ethods in Physics R esearch Section B-B eam Interactions with $M$ aterials and $A$ toms, 172: 530-536.

Rozanski, K., Levin, I., Stock, J., Falcon, R.E.G. \& RuBıo, F. (1995): A tmospheric (CO2)-C-14 variations in the Equatorial region. - Radiocarbon, 37: 509-515.

Ruff, M., Wacker, L., Gaggeler, H.W., Suter, M., Synal, H.A. \& Szidat, S. (2007): A gas ion source for radiocarbon measurements at $200 \mathrm{kV}$. - Radiocarbon, 49: 307-314.

Scott, E.M . (2003a): Part 2: The Third International Radiocarbon Intercomparison (TIRI). - Radiocarbon, 45: 293-328.

Scott, E.M. (2003b): Section 1: The Fourth International Radiocarbon Intercomparison (FIRI). - Radiocarbon, 45: 135-150.

Scott, E.M. (2003c): Section 2: The Results. - Radiocarbon, 45: 151-157.

Scott, E. M., Boaretto, E., Bryant, C., Cook, G.T., Gulliksen, S., Harkness, D.D., Heinemeier, J., M cGee, E., N ay smith, P. \& Possnert, G. (2004): Future needs and requirements for AMS $14 \mathrm{C}$ standards and reference materials. - Nuclear Instruments and M ethods in Physics Research Section B: B eam Interactions with $M$ aterials and A toms, 223-224: 382-387.

Scott, E.M., Cook, G.T. \& Naysmith, P. (2007a): Error and uncertainty in radiocarbon measurements. - Radiocarbon, 49: 427-440.

Scott, E.M., Cook, G.T., Naysmith, P., Bryant, C. $\&$ O'D OnnelL, D. (2007b): A report on phase 1 of the 5th International Radiocarbon Intercomparison (VIRI). - Radiocarbon, 49: 409-426.

Siegenthaler, U., Heimann, M. \& Oeschger, H. (1980): C-14 Variations Caused by Changes in the Global Carbon-Cycle. - Radiocarbon, 22: 177-191.

Spalding, K.L., Bhardwaj, R.D., Buchrolz, B.A., DRUID, H.\& FrISEN, J. (2005a): Retrospective birth dating of cells in humans. - Cell, 122: 133-143.

Spalding, K.L., Buchholz, B.A., Bergman, L.-E., Druid, H.\& Frisen, J. (2005b): ForensicsA ge written in teeth by nuclear tests. - Nature, 437: 333-334.

Stuiver, M. \& Polach, H.A. (1977): Reporting of C-14 Data - Discussion. - Radiocarbon, 19: 355-363.

Stuiver, M. \& Reimer, P. (1989): Histograms Obtained from Computerized Radiocarbon Age Calibration. - Radiocarbon, 31: 817-823. 
Stuiver, M . \& Reimer, P.J . (1986): A Computer-Program for Radiocarbon A ge Calibration. - Radiocarbon, 28: 1022-1030.

SUESS, H.E. (1955): Radiocarbon Concentration in M odern Wood. - Science, 122: 415-417.

Suter, M., Dobeli, M., Grajcar, M., Muller, A., Stocker, M., Sun, G., Synal, H.-A.\& Wacker, $L$. (2007): A dvances in particle identification in A M S at low energies. - Nuclear Instruments and $M$ ethods in Physics Research Section B: Beam Interactions with $M$ aterials and A toms, Accelerator $M$ ass Spectrometry - Proceedings of the Tenth International Conference on A ccelerator $M$ ass Spectrometry, 259: 165-172.

Synal, H.-A., Stocker, M. \& Suter, M. (2007): MICADAS: A new compact radiocarbon AMS system. - Nuclear Instruments and Methods in Physics Research Section B: Beam Interactions with $M$ aterials and A toms, Accelerator $M$ ass Spectrometry - Proceedings of the Tenth International Conference on Accelerator $M$ ass Spectrometry, 259: 7-13.

Synal, H.A., Bonani, G., Dobeli, M., Ender, R.M., Gartenmann, P., Kubik, P.W., Schnabel, C. \& Suter, M . (1997): Status report of the PSI/ETH A M S facility. - N uclear Instruments \& M ethods in Physics Research Section B-Beam Interactions with $M$ aterials and $A$ toms, 123: 62-68.

TAYLOR, R.E., LONG, A.\& KRA, R.S. (1992): Radiocarbon after Four Decades. - 596 S., N ew York (Springer-Verlag).

Turney, C.S.M., Fifield, L.K., Palmer, J.G., Hogg, A.G., Baillie, M.G.L., Galbraith, R., Ogden, J., LORREY, A.\& TIMS, S.G. (2007): Towards a radiocarbon calibration for oxygen isotope stage 3 using New Zealand kauri (A gathis australis). - Radiocarbon, 49: 447-457. van der Plicht, J. \& Hogg, A. (2006): A note on reporting radiocarbon. - Quaternary Geochronology, 1: 237-240.

Van K linken, G.J . \& Hedges, R.E.M . (1998): Chemistry strategies for organic C-14 samples. - Radiocarbon, 40: 51-56.

Venkatesan, M.l., Linick, T.W., Suess, H.E. \& Buccellatı, G. (1982): A sphalt in C-14-Dated A rchaeological Samples from Terqa, Syria.-Nature, 295: 517-519.

Voelker, A.H.L., Grootes, P.M., Nadeau, M.J. \& Sarnthein, M . (2000): Radiocarbon levels in the Iceland Sea from 25-53 kyr and their link to the Earth's magnetic field intensity. - Radiocarbon, 42: 437-452.

Vogel, J.S., Southon, J.R., Nelson, D.E. \& Brown, T.A. (1984): Performance of Catalytically Condensed Carbon for Use in Accelerator M assSpectrometry. - N ucl ear Instruments \& M ethods in Physics Research Section B-Beam Interactions with $M$ aterials and $A$ toms, 233: 289-293.

Vogt, S., Herzog, G.F. \& Reedy, R.C. (1990): Cosmogenic Nuclides in Extraterrestrial Materials. - Reviews of Geophysics, 28: 253-275.

Von Reden, K.F., McNichol, A.P., Pearson, A.\& SChneIder, R.J. (1998): C-14 AMS measurements of $<100$ mu g samples with a high-current system. - Radiocarbon, 40: 247-253.

Wagner, G., Beer, J., Laj, C., Kissel, C., Masarik, J., M uscheler, R. \& Synal, H.-A . (2000): Chlorine-36 evidence for the $M$ ono $L$ ake event in the Summit GRIP ice core. - Earth and Planetary Science L etters, 181: 1-6.

Wang, Y.J., Cheng, H., Edwards, R.L., An, Z. S., Wu, J. Y., Shen, C.C. \& Dorale, J.A. (2001): A high-resolution absolute-dated Late Pleistocene monsoon record from Hulu Cave, China. - Science, 294: 2345-2348. 


\begin{tabular}{|l|l|l|l|}
\hline $\begin{array}{l}\text { Eiszeitalter und Gegenwart } \\
\text { Quaternary Science Journal }\end{array}$ & $\mathbf{5 7 / 1 - 2}$ & $25-51$ & Hannover 2008 \\
\hline
\end{tabular}

\title{
Magnetic dating of Quaternary sediments, volcanites and archaeological materials: an overview
}

\author{
Ulrich Hambach, Christian Rolf \& Elisabeth Schnepp ${ }^{*}$
}

\begin{abstract}
Magnetic dating includes all approaches dealing with the temporal variation of the Earth's magnetic field (EMF) as well as with the application of climate dependent variations of rock magnetic properties of sedimentary sequences and their correlation to independently dated palaeoclimatic archives. Palaeomagnetism has an outstanding impact on geosciences in general and especially on Quaternary chronology and palaeoclimate research. Palaeomagnetic dating employs the temporal variation of the direction as well as the intensity of the EMF on time scales from $10^{2}$ to $10^{7}$ years. The well-known temporal pattern of reversals of the EMF on time scales from $10^{4}$ to $10^{7}$ years and the shorter secular variation (amplitude 10-30 ${ }^{\circ}$, time scale 1 to $10^{3}$ years) provide an excellent tool for stratigraphic subdivisions. Records of the intensity variations of the EMF as well as the indirect dating by means of correlating rock magnetic property variations from sedimentary archives to dated palaeoclimatic records also serve as dating tools. Field methods as well as laboratory methods and techniques in data analysis will not be discussed in this paper. It is our aim to give a short and subjective overview on palaeomagnetism and magnetic susceptibility stratigraphy as dating tools in Quaternary science.
\end{abstract}

[Magnetische Datierung quartärer Sedimente, Vulkanite und archäologischer Materialien: Ein Überblick]

Kurzfassung: Unter magnetischer Datierung versteht man sowohl die Verfahren, die die zeitlichen Variationen des Erdmagnetfeldes (EMF) zur Altersbestimmung benutzen, als auch die Verwendung der klimaabhängigen Änderungen der gesteinsmagnetischen Parameter und ihre Korrelation mit unabhängig datierten paläoklimatischen Archiven. Die Paläomagnetik hat einen herausragenden Einfluss auf die Geowissenschaften genommen und im Besonderen zur Etablierung der Chronologie des Quartärs und der Paläoklimaforschung beigetragen. Die paläomagnetische Datierung benutzt die zeitlichen Variationen der Richtung wie der Intensität des EMFs auf Zeitskalen von $10^{2}$ bis $10^{7}$ Jahren. Das wohlbekannte zeitliche Muster von Polaritätswechseln des EMFs auf Zeitskalen von $10^{4}$ bis $10^{7}$ Jahren wie auch die Säkularvariation (Amplitude 10-30 Zeitskala 1 bis $10^{3}$ Jahre) stellen ein hervorragendes Werkzeug für die Unterteilung von sedimentären oder vulkanischen Gesteinsabfolgen dar. Aufzeichnungen der Änderungen der Intensität des EMFs sowie die indirekte Datierungen über den Vergleich der Variation gesteinsmagnetischer Parameter in Sedimentarchiven mit anderen datierten Paläoklimaserien können ebenfalls zur Datierung herangezogen werden. Weder die Methoden im Gelände und im Labor, noch die Techniken der Datenanalyse werden in dieser Publikation angesprochen. Unser Ziel ist vielmehr, einen kurzen und subjektiven Überblick über die Paläomagnetik bzw. magnetische Suszeptibilitätsstratigraphie als Datierungswerkzeug in der Quartärforschung zu geben.

Keywords: magnetic dating, Quaternary, palaeomagnetism, secular variation, magnetic susceptibility, stratigraphy

* Addresses of authors: U. Hambach, Chair of Geomorphology, Laboratory for Palaeo- and Enviro-Magnetism (PUM), University of Bayreuth, 94450 Bayreuth, Germany. E-Mail: ulrich.hambach@uni-bayreuth.de; C. Rolf, Leibniz Institute for Applied Geosciences (GGA), Stilleweg 2, 30655 Hannover, Germany. E. Schnepp, Chair of Geophysics, University of Leoben, Gams 45, 8130 Frohnleiten, Austria 